\title{
Evaluation of Genotypic and Phenotypic Biofilm Formation by Staphylococcus aureus Isolated from Clinical Samples and Their Association with Antimicrobial Resistance
}

\author{
Hossein Ghaderi ${ }^{1}$, Ebadallah Shiri Malekabad ${ }^{2}$, Mahmoud Vahidi $^{3}$, Ali-Reza Dadashi ${ }^{* 4}$
}

1. Department of Bacteriology, School of Veterinary Science, Shiraz University, Shiraz. Iran.

2. Department of Biostatistics, AJA University of Medical Sciences, Tehran, Iran.

3. Department of Medical Laboratory Sciences, School of Allied Medical Sciences, AJA University of Medical Sciences, Tehran, Iran.

4. Infectious Disease Department, AJA University of Medical Sciences, Tehran, Iran

\section{ABSTRACT}

Background: Staphylococcus aureus is one of the most important bacteria causes nosocomial infections, which by the biofilm formation can be effective in the creation of chronic diseases, and the creation and strengthening of drug resistance. The present study aimed to evaluate the genotypic and phenotypic biofilm formation by $S$. aureus isolated from clinical samples and their association with antimicrobial resistance.

Materials \& Methods: In this descriptive cross-sectional study from Dec 2019 to Sep 2019, 200 clinical samples were obtained from AJA hospitals in Tehran. All samples were analyzed using blood agar, Baird-Parker Agar, mannitol salt agar and catalase, OF and coagulase assays. Antimicrobial resistance pattern of isolates was determined by the disc diffusion method. Multiplex PCR method was used to identify biofilm formation genes, includes icaA, icaB, icaC, and icaD genes. Data analyzed using SPSS 20 and the $X^{2}$ test.

Results: Out of 200 cultivated samples, 83 (41.5\%) cases were confirmed as S. aureus. The highest resistance was observed to Penicillin (94\%), Tetracycline (72\%), Ampicillin (54\%), and Cefoxitin (51\%), respectively. Phenotypic biofilm formation ability reported in $65 \%$ of isolates. The frequency of presence of icaA, icaB, icaC, and icaD genes was estimated at $67.4 \%$, $60.2 \%, 61.4 \%$, and $62.6 \%$, respectively. Eighty-seven percent of biofilm producing strains were multidrug-resistant, while all the biofilm negative strains were non- multiple drug resistance $(P<0 / 05)$.

Conclusion: According to the results, Biofilm-positive strains have a very high propensity to demonstrate antimicrobial resistance, multidrug resistance and resistance to methicillin.

Keywords: Staphylococcus aureus, Biofilm, Antimicrobial Resistance, MRSA

\begin{tabular}{|c|c|c|c|c|}
\hline \multicolumn{3}{|c|}{ Received: 2020/05/14; } & Accepted: 2020/08/31; & Published Online: 2020/09/26 \\
\hline \multicolumn{2}{|c|}{ Corresponding Information: } & $\begin{array}{l}\text { Ali-Reza Dadashi, I } \\
\text { Email: } \text { drdadashial }\end{array}$ & $\begin{array}{l}\text { uns Disease Department, AJAU } \\
\text { @gmail.com }\end{array}$ & ity of Medical Sciences, Tehran, Iran. \\
\hline (ख) & \multicolumn{4}{|c|}{$\begin{array}{l}\text { Copyright } \odot \text { 2020, This is an original open-access article distributed under the terms of the Creative Commons Attribution-noncommercial } 4.0 \text { International License which } \\
\text { permits copy and redistribution of the material just in noncommercial usages with proper citation. }\end{array}$} \\
\hline \multicolumn{5}{|c|}{ Use your device to scan and read the article online } \\
\hline 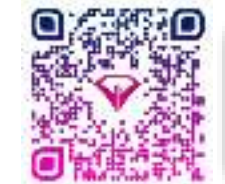 & \multicolumn{4}{|c|}{$\begin{array}{l}\text { Ghaderi H, Shiri Malekabad E, Vahidi M, Dadashi A. Evaluation of genotypic and phenotypic biofilm } \\
\text { formation by Staphylococcus aureus isolated from clinical samples and their association with } \\
\text { antimicrobial resistance. Iran J Med Microbiol. 2020; } 14 \text { (5):441-459 }\end{array}$} \\
\hline
\end{tabular}

Download citation: BibTeX | RIS | EndNote | Medlars | Procite | Reference Manager | RefWorks

$$
\text { Send citation to: } \approx \underline{\text { Mendeley }} \mathbf{z} \text { Zotero } \underline{\text { RefWorks }}
$$

\section{Introduction}

Biofilm is the aggregation of bacteria embedded in an extracellular matrix that can create on both abiotic and biotic surfaces (1). This layer provides ideal conditions for bacteria to grow in unstable environments. The most important features of biofilm are bacterial survival in extreme environmental 
conditions, role in pathogenicity and creating chronic diseases, strengthening drug resistance through antibiotic impermeability in the polymeric matrix, facilitate gene transfer through conjugation and increase genetic mutations due to these bacterial connections, development of new genotypic strains by mutation within the biofilm and activation of genes that they are responsible for bacterial virulence $(2,3)$. $S$. aureus is one of the pathogens that can cause disease in humans and animals (4). This bacterium is the cause of many diseases in humans, included skin infections, acute and invasive infections such as pneumonia, soft tissue and bone infections, heart valve infections and lethal sepsis. It is one of the most important causes of bacteremia and is responsible for $20-40 \%$ of deaths $(5,6)$. In addition to resistance, this bacterium has the ability to produce various pathogenic factors such as toxins, surface antigens, extracellular enzymes and biofilm production $(6,7)$.

In S. aureus, the pathogenicity of the biofilm is very important. The presence of this layer is encoded by a structural operon called intra cellular adhesin (ica), which has different gene locus including icaA, icaD, $i c a B$ and $i c a D(8,9,10)$. The icaA gene is a primary inducer for start biofilm production. It is activated by the presence of UDP-N-acetyl glucosamine and is the only ica gene that has transferase properties. The IcaD protein is a messenger (chaperone) for other genes in this locus that helps the icaA gene, activates certain enzymes to express the ica $C$ and icaD genes. When the $i c a A$ and icaD genes start cooperation, biofilm production increases 20 times $(9,10)$. The icaC gene communicates between the inside and outside of the bacterial cytoplasmic membrane, that it communicates the IcaD on the inside of the cytoplasmic membrane to the IcaB on the outside. The IcaB is the extracellular protein and cause the superficial association of the bacterium with intercellular adhesion polysaccharide (IAP). One of the factors that increases the expression of this operon is the relationship between IcaB and IPA, that more correlation leads to more biofilm production (11).

Biofilms in hospital environments, that are considered as a reservoir of infection transmission, responsible for causing $65 \%$ of nosocomial infections (12). Biofilm binds bacteria to surfaces and other hospital instruments and in this way, to provide the ground for infection in hospitalized people and users of these medical devices (13). In order to prevent the formation of biofilm and subsequent microbial resistance, increased hospitalization, increased costs, and increased mortality (especially in antibioticresistant $S$. aureus); proper use of antibiotics (under the supervision) as well as arbitrarily use of drugs and antimicrobial compounds, regular evaluation of resistance and expression of related genes at the hospital can greatly reduce the incidence of these problems.
Due to the high prevalence of nosocomial infections caused by $S$. aureus and also the spread of factors that increase antibiotic resistance, the present study aimed to evaluate the genotypic and phenotypic biofilm formation by $S$. aureus isolated from clinical samples and their association with antimicrobial resistance.

\section{Materials and Methods}

This descriptive cross-sectional study from Dec 2019 to Sep 2019 was conducted in the School of Paramedical Sciences, AJA University of Medical Sciences. The present study investigated by the ethics committee of the AJA University of Medical Sciences and approved with the code IR.AJAUMS.REC.1397.087. Using the formula for calculating the sample size and according to the results of similar studies $(3,10), 200$ samples were calculated.

A total of 200 clinical samples from 63 patients admitted to different wards of AJA hospitals in Tehran were collected. Samples included blood (63 samples), urine (63), catheter (23 samples), discharge (17), ulcers (16 samples), sputum (12 samples), and nasal swabs (6 samples) which were referred to the paramedical faculty of the AJA University of Medical Sciences under sterile conditions. Inclusion criteria to study were included hospitalization in different wards of the hospital and long-term treatment with various antibiotics, and exclusion criteria were included outpatient treatment (no hospitalization) and no longterm use of antibiotics.

The samples were first cultured on blood Agar medium and incubated for $24 \mathrm{~h}$ at $37^{\circ} \mathrm{C}$. After observing the colonies, standard biochemical tests were performed to confirm the isolates including catalase test, Gram-staining, and then bacterial culture on mannitol salt agar media (mannitol fermentation test), Baird-Parker agar (formation of black colonies with clear and opaque halos), DNase and coagulase tests (14).

\section{Antimicrobial Susceptibility Test}

This test performed by Müller-Hinton agar (MHA) using the standard antibiotic disk including penicillin (10 IU), ciprofloxacin (5 $\mathrm{gg})$, chloramphenicol (30 $\mu \mathrm{g})$, gentamicin $(10 \mu \mathrm{g})$, doxycycline $(30 \mu \mathrm{g})$, Tetracycline $(30 \mu \mathrm{g})$, clindamycin $(2 \mu \mathrm{g})$, cotrimoxazole $(25 \mu \mathrm{g})$, ampicillin $(15 \mu \mathrm{g})$, erythromycin $(15 \mu \mathrm{g})$, cephalothin $(30 \mu \mathrm{g})$ and cefoxitin $(30 \mu \mathrm{g})$, purchased from HiMedia company (Mumbai, India). $(10,14)$. The isolates were further screened for methicillin resistance by the cefoxitin disk (15). In these tests, S. aureus ATCC 33591 was used as a positive control. The results exegesis conducted using Clinical and Laboratory Standards Institute guidelines (16). 


\section{Phenotypic Evaluation of Biofilm Producing Strains}

Congo red and a modified microtiter plate (MTP) assay were used to identify biofilm-producing strains. Confirmed isolates were cultured on brain heart infusion (BHI) agar medium containing $0.8 \mathrm{~g} / \mathrm{L}$ Congo red and $36 \mathrm{~g} / \mathrm{L}$ sucrose. After $24 \mathrm{~h}$ of incubation at $37^{\circ} \mathrm{C}$, black colonies as strong biofilms, dark red colonies as weak biofilms and light red colonies as negative biofilm strains were considered (17).

To quantitatively evaluate the production of biofilm by MTP assay, from the samples enriched on trypticase soy broth (TSB) medium, turbidity equivalent to 0.5 McFarland was prepared and then $200 \mu \mathrm{L}$ of each suspension was transferred to wells of 96-well polyester microplate and incubated for $20 \mathrm{~h}$ at $37^{\circ} \mathrm{C}$. Then, the wells washed (4 times) using phosphate buffered saline (PBS) and dried completely. Next, the wells were stained with crystal violet dye (1\%) for 15 minutes and to remove the dye from the bacterial wall, $100 \mu \mathrm{L}$ of a mixture of isopropyl alcohol $10 \%$ and ethanol $70 \%$ was added to each well. Finally, the light absorption of each well at $570 \mathrm{~nm}$ was investigated using an ELISA reader. Finally, the optical density (OD) of the wells were measured using an ELISA reader at a wavelength of $570 \mathrm{~nm}$. The test was conducted in triplicate. Exegesis of results were performed as per the criteria explained (18) and the bacteria were divided into weak (non-producer), moderate and strong biofilm producers. S. aureus ATCC 25923 was used as positive control, for the biofilm assay.

\section{DNA Extraction}

DNA extraction was performed by the boiling technique using lysis buffer ( $1 \%$ Triton $x 100,0.5 \%$ Tween 20, Tris $10 \mathrm{mmol}$ with $\mathrm{pH}: 8$ and EDTA $1 \mathrm{mmol}$ ) (19).

\section{Molecular Confirmation of $S$. aureus Isolates}

Amplifying the thermonuclease gene by polymerase chain reaction (PCR) was used for molecular confirmation of isolates (Table 1). For this test, distilled water and S. aureus ATCC 33591 were utilized as negative and positive controls, respectively. The final volume of each reaction was considered to be 20 $\mu \mathrm{L}$ and the PCR reaction temperature program is shown in table 2. The products of PCR were evaluated using $1 \%$ agarose gel and UV transilluminator. Samples with 279 bp band were considered as S. aureus (20).

\section{Molecular Identification of Biofilm-Producing Strains}

Amplification of icaABCD operon genes (with icaA, $i c a D$, ica $C$ and icaB genes) was used to identify biofilmproducing strains by PCR (Table 1). Distilled water and S. aureus ATCC 25923 were used as negative and positive controls, respectively, for this test. The final volume of each reaction was considered to be $20 \mu \mathrm{L}$ and the PCR reaction temperature program of this operon is shown in Table 2. The products of PCR were evaluated using $1 \%$ agarose gel and UV transilluminator. The size of products of the genes are shown in Table 1 (21).

\section{Statistical Analysis}

Data are analyzed by SPSS 20 (SPSS Inc., Chicago, IL., USA). $X^{2}$ (Chi-square) test was utilized for data analysis. $\mathrm{P}$-value $<0.05$ was considered statistically significant.

Table 1. Primers used in the study

\begin{tabular}{|c|c|c|c|}
\hline Gene & Product size (bp) & Primer sequence & Reference \\
\hline пис & 279 & $\begin{array}{c}\text { F: GCGATTGATGGTGATACGGTT } \\
\text { R: AGCCAAGCCTTGACGAACTAAAGC }\end{array}$ & 20 \\
\hline$i c a A$ & 188 & $\begin{array}{l}\text { F: ACACTTGCTGGCGCAGTCAA } \\
\text { R:TCTGGAACCAACATCCAACA }\end{array}$ & 21 \\
\hline$i c a B$ & 880 & $\begin{array}{l}\text { F: AGAATCGTGAAGTATAGAAAATT } \\
\text { R: TCTAATCTTTTTCATGGAATCCGT }\end{array}$ & 21 \\
\hline$i c a C$ & 1066 & $\begin{array}{c}\text { F: ATGGGACGGATTCCATGAAAAAGA } \\
\text { R: TAATAAGCATTAATGTTCAATT }\end{array}$ & 21 \\
\hline$i c a D$ & 198 & $\begin{array}{c}\text { F: ATGGTCAAGCCCAGACAGAG } \\
\text { R: AGTATTTTCAATGTTTAAAGCAA }\end{array}$ & 21 \\
\hline
\end{tabular}

Table 2. PCR reaction program (30 cycles)

\begin{tabular}{|ccccc|}
\hline & & \multicolumn{2}{c|}{ Steps, temperature and time of PCR reaction } \\
\hline Gene & Primary denaturation & Denaturation & Annealing & Extension \\
\hline$n u c$ & $94^{\circ} \mathrm{C}, 5 \mathrm{~min}$ & $94^{\circ} \mathrm{C}, 30 \mathrm{sec}$ & $55^{\circ} \mathrm{C}, 55 \mathrm{sec}$ & $72^{\circ} \mathrm{C}, 60 \mathrm{sec}$ \\
\hline$i c a A$ & $94^{\circ} \mathrm{C}, 5 \mathrm{~min}$ & $94^{\circ} \mathrm{C}, 60 \mathrm{sec}$ & $55^{\circ} \mathrm{C}, 60 \mathrm{sec}$ & $72^{\circ} \mathrm{C}, 60 \mathrm{sec}$ \\
\hline$i c a B$ & $94^{\circ} \mathrm{C}, 5 \mathrm{~min}$ & $94^{\circ} \mathrm{C}, 60 \mathrm{sec}$ & $52^{\circ} \mathrm{C}, 30 \mathrm{sec}$ & $72^{\circ} \mathrm{C}, 90 \mathrm{sec}$ \\
\hline$i c a C$ & $94^{\circ} \mathrm{C}, 5 \mathrm{~min}$ & $94^{\circ} \mathrm{C}, 60 \mathrm{sec}$ & $55^{\circ} \mathrm{C}, 30 \mathrm{sec}$ & $72^{\circ} \mathrm{C}, 30 \mathrm{sec}, 10 \mathrm{~min}$ \\
\hline$i c a D$ & $94^{\circ} \mathrm{C}, 5 \mathrm{~min}$ & $94^{\circ} \mathrm{C}, 0 \mathrm{sec}$ & $55^{\circ} \mathrm{C}, 30 \mathrm{sec}$ & $72^{\circ} \mathrm{C}, 60 \mathrm{sec}$ \\
\hline
\end{tabular}




\section{Results}

Out of 200 cultured clinical specimens, 83 (41.5\%) cases were phenotypically identified as $S$. aureus; 23 isolates (27.71\%) from urine, 17 isolates $(20.48 \%)$ from catheter, 15 isolates (18.07\%) from blood, 12 isolates (14.45\%) from wound, 9 isolates (10.84\%) from secretions, 5 isolates (6.02\%) from nasal swabs and 2 isolates (2.40\%) from sputum were isolated, that all phenotypically confirmed isolates had nuc gene by molecular tests (Figure 1).

\section{Antimicrobial Resistance Patterns}

The results of the antimicrobial resistance test are shown in Table 3.

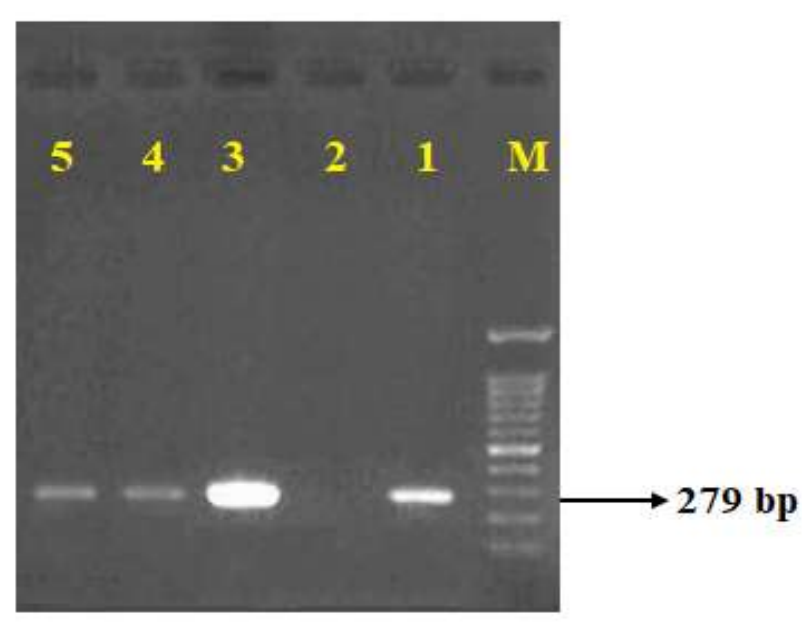

Figure 1. Electrophoresis of nuc gene PCR product lane M -marker $100 \mathrm{bp}$, lane 1- Positive control (S. aureus ATCC33591), lane 2- Negative control (distilled water), lanes 3 to 5- Study samples

Table 3. Antibiogram test results of Staphylococcus aureus isolates

\begin{tabular}{|c|c|c|c|}
\hline Antibiotic & Resistant/n (\%) & Intermediate/ n (\%) & Sensitive/ n (\%) \\
\hline Penicillin (10 IU) & $78\left(94^{*}\right)$ & - & $5(6)$ \\
\hline Ciprofloxacin $(5 \mu \mathrm{g})$ & $35(43)$ & $2(2)$ & $46(55)$ \\
\hline Tetracycline $(30 \mu \mathrm{g})$ & $60(72)$ & $10(12)$ & $13(16)$ \\
\hline Chloramphenicol $(30 \mu \mathrm{g})$ & $36(43)$ & $24(29)$ & $23(28)$ \\
\hline Cefoxitin $(30 \mu \mathrm{g})$ & $42(51)$ & - & $41(49)$ \\
\hline Gentamicin $(10 \mu \mathrm{g})$ & $37(45)$ & $1(1)$ & $45(54)$ \\
\hline Erythromycin $(15 \mu \mathrm{g})$ & $36(43)$ & $3(4)$ & $44(53)$ \\
\hline Cephalothin $(30 \mu \mathrm{g})$ & $27(33)$ & $12(14)$ & $44(53)$ \\
\hline Ampicillin $(15 \mu \mathrm{g})$ & $45(54)$ & $9(11)$ & $29(35)$ \\
\hline Clindamycin $(2 \mu \mathrm{g})$ & $23(28)$ & - & $60(72)$ \\
\hline Cotrimoxazole (25 $\mu \mathrm{g})$ & $32(39)$ & $4(5)$ & $47(56)$ \\
\hline Doxycycline $(30 \mu \mathrm{g})$ & $3(4)$ & $5(6)$ & $75(90)$ \\
\hline
\end{tabular}

* Percentages are rounded

The highest resistance of isolates was to penicillin (94\%), tetracycline (72\%), ampicillin (54\%) and cefoxitin (51\%), respectively, and the highest susceptibility of isolates was reported to doxycycline (90\%), clindamycin (72\%), cotrimoxazole (56\%) and ciprofloxacin (55\%), respectively. Based on the results, $51 \%$ (42 cases) of isolates were considered as Methicillin-resistant $S$. aureus (MRSA) strains.

\section{Biofilm Formation}

According to the results of the Congo red test, out of 83 isolates, $23(27.70 \%)$ isolates had a black colony (strong biofilm), 31 (37.30\%) isolates had a dark red colony (weak biofilm) and 29 (35\%) isolates with bright red colonies (lacking the ability to produce biofilm). The results of quantitative biofilm formation test
(MTP) showed that 29 (35\%) isolates had strong biofilm, 25 (30\%) isolates had weak biofilm and 29 (35\%) isolates lacked the ability to produce biofilm. Overall, 54 (65\%) isolates were considered as positive biofilm strains.

Based on the results of table 4, a statistically significant difference was observed between qualitative results (Congo red) and quantitative results (MTP) of biofilm production by chi-square test $(P<0.05$, 0.001, $\left.X^{2}=54.9, d f=4\right)$.

As shown in Table 5, there is a statistically significant difference between the microbial resistance of positive and negative biofilm of $S$. aureus strains to the antibiotics of ciprofloxacin, cefoxitin, gentamicin, erythromycin, cephalothin and cotrimoxazole $(P<0.05)$. 
Table 4. Comparison of quantitative (Congo red) and qualitative (MTP) test results of biofilm production

\begin{tabular}{|ccccc|}
\hline MTP test & Strong adherence & weak adherence & No adhesion \\
\hline Congo red test & 17 & 6 & 0 & 23 \\
\hline Black colony & 12 & 19 & 0 & 31 \\
\hline Dark red colony & 0 & 0 & 29 & 29 \\
\hline Bright red colonies & 29 & 25 & 83 \\
\hline Total & & 29 & 29 \\
\hline
\end{tabular}

Table 5. Comparison of antimicrobial resistance pattern in biofilm-negative and biofilm- positive isolates

\begin{tabular}{|c|c|c|c|}
\hline Antibiotic & $\mathrm{BP}^{1}(\mathrm{n}=54) / \mathrm{n}(\%)$ & $\mathbf{B N}^{2}(\mathrm{n}=29) / \mathrm{n}(\%)$ & P-value \\
\hline Penicillin & $54(100 *)$ & $24(83)$ & 0.465 \\
\hline Ciprofloxacin & $33(61)$ & $2(7)$ & 0.026 \\
\hline Tetracycline & $42(78)$ & $18(62)$ & 0.185 \\
\hline Chloramphenicol & $25(46)$ & $11(38)$ & 0.505 \\
\hline Cefoxitin & $40(74)$ & $2(7)$ & 0.007 \\
\hline Gentamicin & $37(100)$ & - & 0.002 \\
\hline Erythromycin & $36(100)$ & - & 0.002 \\
\hline Cephalothin & $27(100)$ & - & 0.002 \\
\hline Ampicillin & $31(57)$ & $14(48)$ & 0.427 \\
\hline Clindamycin & $17(31)$ & $6(21)$ & 0.315 \\
\hline Cotrimoxazole & $32(100)$ & - & 0.002 \\
\hline Doxycycline & $2(3)$ & $1(3)$ & - \\
\hline
\end{tabular}

1. Biofilm producer

2. Biofilm non-producer

Percentages are rounded

Of the total isolates, $47(57 \%)$ were multidrugresistant that included all biofilm-positive isolates, 47 (57\%), while 7 (13\%) were non-MDR. All the biofilm negative isolates were non-MDR isolates $(P<0.05 ;$ Table 6$)$. Also, 24 (29\%) of the isolates were MRSA. It is worth noting, $44 \%$ of biofilm positive isolates were MRSA, while all biofilm negative isolates were methicillin-sensitive $S$. aureus (MSSA) $(P<0.05 ;$ Table 6$)$. There was a statistically significant difference between the type of strain and biofilm production by $X^{2}$ test $\left(P<0.050 .001, X^{2}\right.$ $=108.1, \mathrm{df}=3$ ).

Table 6. Comparison of MDR and resistance to methicillin in biofilm-negative and biofilm-positive isolates

\begin{tabular}{|c|c|c|c|c|}
\hline Isolate type & $\mathrm{MDR}^{1}, \mathbf{n}(\%)$ & Non-MDR, n (\%) & MRSA, n (\%) & $\mathrm{MSSA}^{2}, \mathrm{n}(\%)$ \\
\hline $\begin{array}{l}\text { Biofilm producer } \\
\qquad(\mathrm{n}=54)\end{array}$ & $47\left(87^{*}\right)$ & 7 (13) & $24(44)$ & $30(56)$ \\
\hline $\begin{array}{l}\text { Biofilm non-producer } \\
\qquad(\mathrm{n}=29)\end{array}$ & $0(-)$ & $29(100)$ & $0(-)$ & $29(100)$ \\
\hline $\begin{array}{c}\text { Total } \\
(n=83)\end{array}$ & $47(57)$ & $36(43)$ & $24(29)$ & $59(71)$ \\
\hline
\end{tabular}

1- Multidrug-resistant

2- Methicillin-sensitive S. aureus

* Percentages are rounded

\section{Molecular Evaluation of ica $A B C D$ Operon}

In the Molecular evaluation of ica $A B C D$ operon, the frequency of $i c a A, i c a B$, icaC and icaD genes were $67.4 \%$ (56 isolates), 60.2\% (50 isolates), 61.4\% (51 isolates) and $62.6 \%$ (52 isolates), respectively. Accordingly, the most common gene encoding biofilm production in the studied isolates are icaA and icaD genes. Out of 83 isolates, 50 isolates $(60 \%)$ had both $i c a A$ and $i c a D$ genes and 34 isolates (41\%) had all ica operon genes. There was not statistically significant difference between the presence of ica operon genes in S. aureus isolates. 


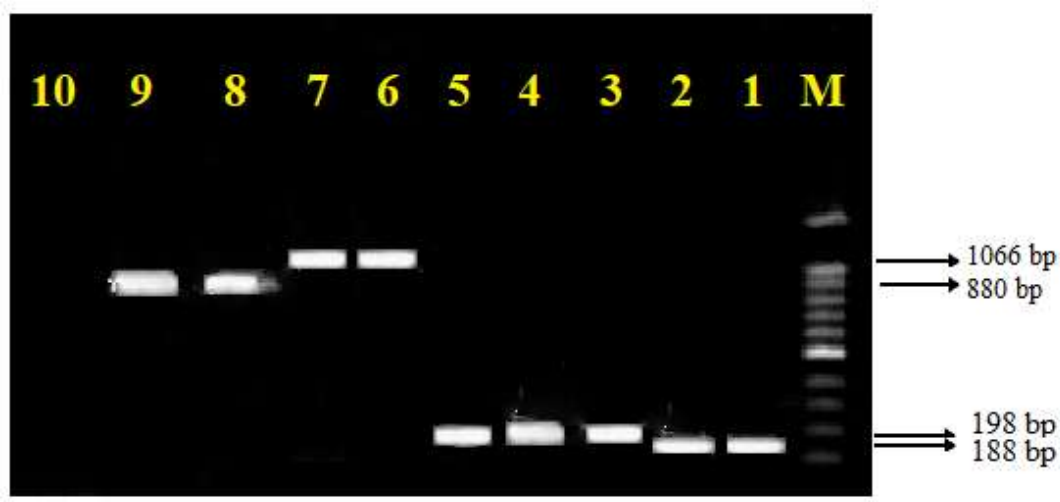

Figure 2. Electrophoresis of ica operon genes PCR products

lane $\mathrm{M}$-marker $100 \mathrm{bp}$, lanes 1 and 2-positive samples for icaA gene (188 bp), lanes 3 to 5 - positive samples with icaD gene (198 bp), lanes 6 and 7- positive samples for icaC gene (1066 bp), lanes 8 and 9- positive samples for icaB gene ( 880 bp), lane 10- Negative control (distilled water)

\section{Discussion}

According to the results of this study, the prevalence of $S$. aureus in clinical specimens was $41.5 \%$. The results of various studies have shown similarities and differences in this field, including: Neopane et al. (2018) in Nepal reported that the prevalence of $S$. aureus in clinical specimens is $28.66 \%$ (11). In another study in India (2018), Manandhar et al reported a prevalence $43 \%$ of this bacterium in clinical specimens (23). In a similar study in Tehran that it conducted by Mashaiekhi and Amini (2018), the prevalence of $S$. aureus was calculated to be $17.09 \%$ (24). The difference in the prevalence of $S$. aureus in clinical specimens may be related to differences in specimen type, geographical location, sampling time, sampling location, etc.

Based on the results of antibiogram test in the present study, the highest resistance of isolates was to penicillin (94\%), tetracycline (72\%), ampicillin (54\%), cefoxitin (51\%) and gentamicin (37\%), respectively. The results of Nourbakhsh and Momtaz's study (2016) showed that the highest resistance of $S$. aureus isolates in clinical samples was related to penicillin $(100 \%)$ and tetracycline $(76 \%)$, which is consistent with the results of the present study (25). In the study of Sadri et al., resistance to tetracycline was reported to be $42 \%$ (26). In the study of Ahmadi et al., $20 \%$ resistance to gentamicin was reported in Kermanshah, also, the resistance to ampicillin was reported to be $55 \%$ (27). $23 \%$ resistance of S. aureus strains to gentamicin was also observed in the study of Hauschild et al. (28). A study by Mirzaee et al. in Tehran showed that more than $80 \%$ of $S$. aureus isolates are ampicillinresistant (29). The present study shows the high prevalence of MRSA strains (51\%) in different wards of AJA hospitals that comparing these results with the results of other studies in this field, showed many differences and similarities. Abdollahi et al. (2011) in Fars reported thet the rate of methicillin-resistance in $S$. aureus isolates was $47.56 \%$ (30). Also, several studies were conducted on the prevalence of MRSA islolates, which $43.5 \%, 50 \%, 12.6 \%$ and $30 \%$ of isolates in the study of Abu-Shady et al. (31), Hassanzadeh et al. (34), Tabaei et al. (32) and Rahimi et al. (33), were resistant to methicillin, respectively. The resistance of $S$. aureus isolates to methicillin can be due to overuse of antimicrobial compounds for disinfecting hospital environments, treatment of infections, transfer of patients colonized with these strains from one hospital to another, etc (22). As a result, it is necessary to monitor the use of drugs and disinfectant compounds, teach the correct methods of using antibiotics and infection control proceedings in all wards of hospitals.

Numerous studies on the pattern of antibiotic resistance of S.aureus isolates have been published from different wards of hospitals in different regions that are consistent or inconsistent with the results of our study. In the study of Ahmadi et al. (2014), the highest antibiotic resistance was reported to penicillin, tetracycline, methicillin and ampicillin (27). Also, in the study of Hatefizade et al. in Tehran (2016), the highest resistance to penicillin and ampicillin was observed (35), which these results were consistent with the results of the present study. In 2017, a study was conducted by Motamedi et al. in Hamedan. The results of this study showed that the highest antibiotic resistance is to erythromycin (36), which is in contrary to the results of the present study. These differences in the results can be due differences in a geographical area, the hygienic status of hospital wards (34) as well as creating chromosomal resistance during generation or transmission of resistance factors between bacterial species (36).

In the present study, in addition to emphasizing the spread of multiple drug resistance in clinical specimens, the ability to produce biofilm as a 
phenotype was reported to be 65\%; This was consistent with the results of studies by Namvar et al. (2013) (13) and Croes et al. (2009) (37). In a similar study by Gad et al. (2009), the ability to produce biofilm was reported in $83 \%$ of isolates (38). In another study in Nepal conducted by Neopane et al. (2018), biofilm-producing strains were reported about $70 \%$ (10). Various factors can contribute to biofilm formation, including environmental factors (such as sugars, or proteases in the growth medium), nutrient availability, geographical origin, sample type, area surface (rough or smooth), porosity, Environmental stresses (such as antibiotic exposure), surface adhesion characteristics, and bacterial genetic arrangement. Furthermore, mutations in the ica operon genes and the regulatory genes of this operon are associated with a reduction in the ability of $S$. aureus to produce biofilms (10).

In the present study, the frequency of icaA, icaB, $i c a C$ and icaD genes were $67.4 \%$ (56 isolates), $60.2 \%$ (50 isolates), $61.4 \%$ (51 isolates) and $62.6 \%$ (52 isolates), respectively, which is consistent with the results of Nourbakhsh and Momtaz's study in 2016 (25). In a study by Eftekhar et al. (2011), 73\% of the isolates contained the icaA and icaB genes (22). Also, in the study of Namvar et al., all isolates have had icaC gene (13). In the present study, $60 \%$ of the isolates had both icaA and icaD genes and $41 \%$ of the isolates had all the ica operon genes, while strong biofilm was observed in only $35 \%$ of the isolates. In the study of Mirzaee et al. (2014) in Tehran, it was found that about $28 \%$ of the isolates had all the ica operon genes, while only half of these isolates were able to form a strong biofilm (29). In the Mashaiekhi and Amini's study (2016), $75 \%$ of $S$. aureus isolates have had both $i c a A$ and icaD genes (24). In the study of the presence of genes and phenotypic biofilm formation, differences were observed that depending on the factors mentioned earlier. Therefore, the presence or absence of a gene alone can't play a major role in biofilm formation. In the present study, there were two genes (icaA and icaD) in $60 \%$ of isolates and there were in $41 \%$ of isolates all of ica operon genes. The Isolates were placed between strong and weak spectra in biofilm formation, but none of these isolates were seen with the inability to form biofilms.

\section{Conclusion}

Pursuant to the results of this study, S. aureus isolates have had high resistance to most of the studied antibiotics (especially methicillin). Also, the significant abundance of biofilm-producing genes in these isolates can be effective in increasing the multiple drug resistance, persistence of bacteria in the environment (especially in hospital environments). In the present study, there was a statistically significant relationship between biofilm formation and antibiotic resistance $(P<0.05)$. The presence of biofilm-producing genes and their role in antibiotic resistance can have consequences such as prolonged hospitalization, increased costs, and increased mortality (especially those admitted to the burn ward, immunosuppressed patients, and those undergoing aggressive treatments such as the use of artificial implants).

\section{Acknowledgment}

The authors thank the Research Assistance of AJA University of Medical Sciences and the staff of AJA hospitals in Tehran for their assistance in conducting this study.

\section{Conflict of Interest}

Authors declared no conflict of interests. 


$$
\begin{aligned}
& \text { مجله ميكروبشناسى يزشكى ايران }
\end{aligned}
$$

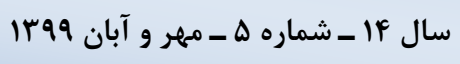

$$
\begin{aligned}
& \text { Journal homepage: www.ijmm.ir }
\end{aligned}
$$

\title{
بررسى فنوتيِى و زنوتيِى تشكيل بيوفيلم توسط /ستافيلوكوكوس اورئوسهاى جداشده

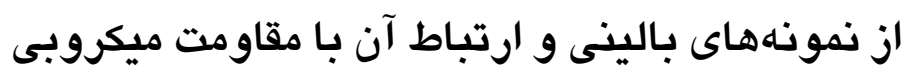

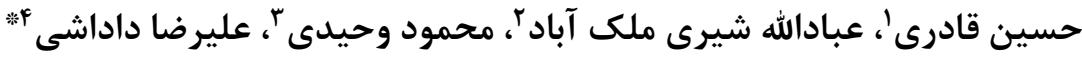

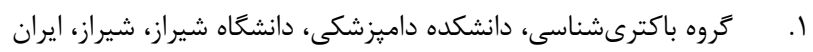

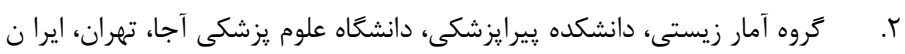

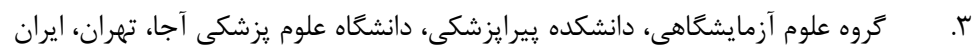

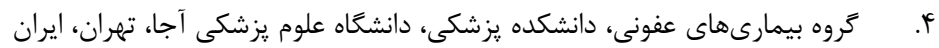

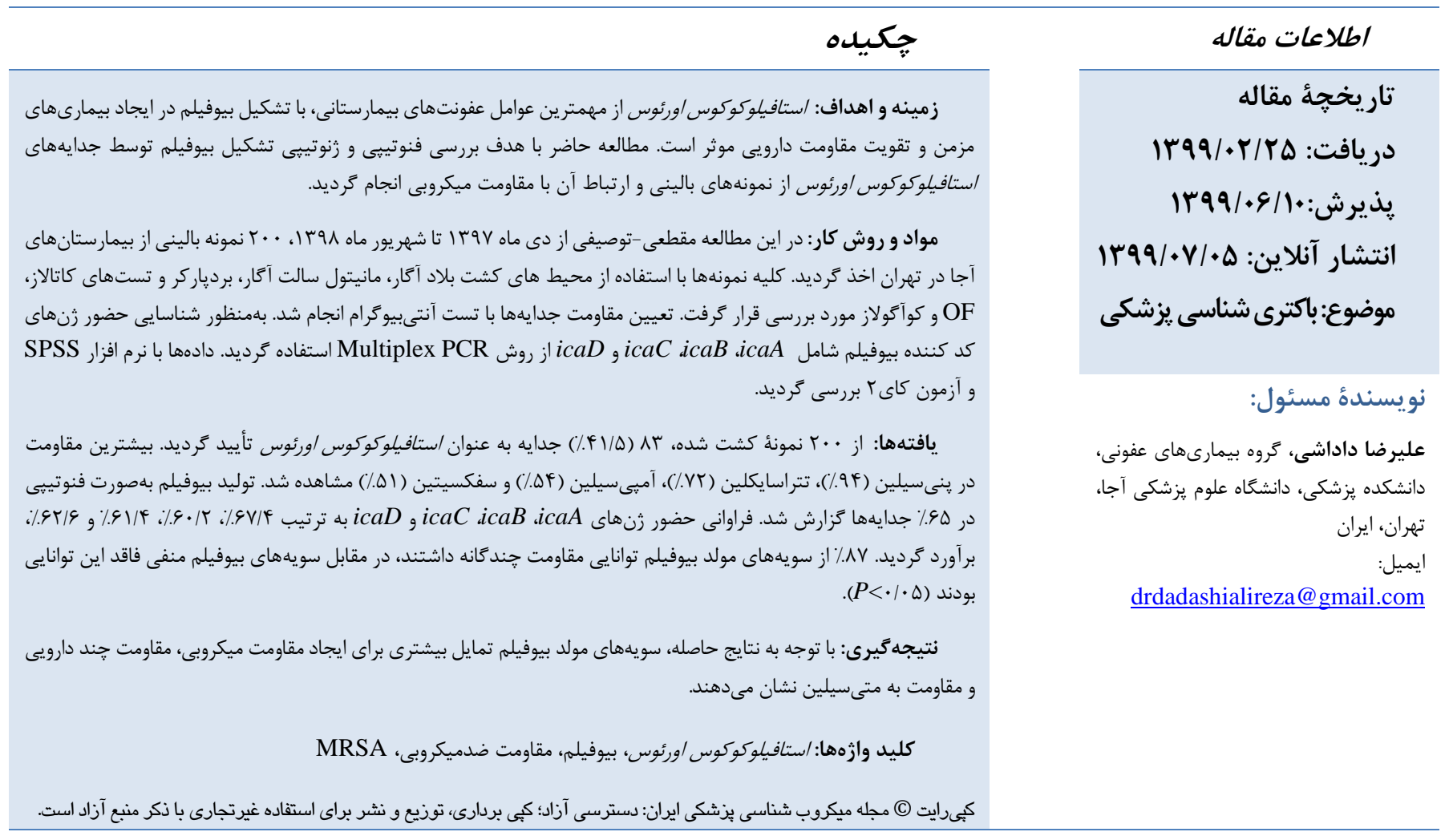

مقدمه

نفوذنايذيرى آنتىبيوتيك در ماتريكس يليمرى، تسهيل در انتقال زن از طريق كانزوكاسيون و افزايش جهشىهاى زنتيكى بلهواسطه اين اتصالات باكتريايى، بلوجود آمدن سويههاى زنوتييى جديد در اثر موتاسيون يا جهش در داخل بيوفيلم و فعال شدن زنهائ بـن مسئول

$$
\text { ويرولانس باكترى در شكل بيوفيلم، اشاره كرد (r و ب). }
$$

استافيلوكوكوس /ورئوس يكى از مهمترين باكترىهاى بيمارىزا است كه مىتواند در انسان و حيوانات ايجاد بيمارى كند
بيوفيلم شامل مجموعه اى از ميكروار كانيسمها است كه در سطح و ماتريكس يك جسم غير زنده و يا يك موجود زنده به هم متصل شده و سبب ايجاد يك سطح زلهاى مىشوند (1). اين لايه علاوه بر اينكه محيطى مناسب براى باكترى فراهم مى كند، شرايط ايدئالى را براى رشد و تكثير آن در محيطهاى نايايدار بلوجود مى آورد.

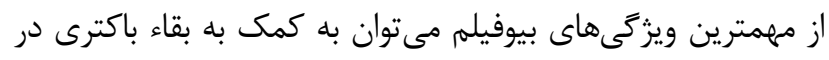

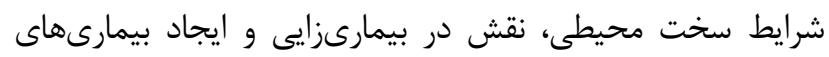

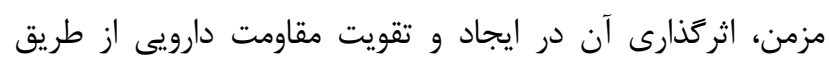


كنندكان اين وسايل يزشكى را فراهم كند (سا). بهمنظور جلوَّيرى ازتشكيل بيوفيلم و متعاقب آن ايجاد مقاومتهاى ميكروبى، افزايش

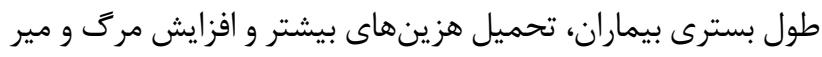

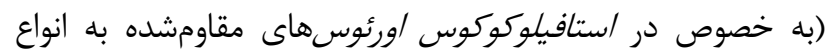

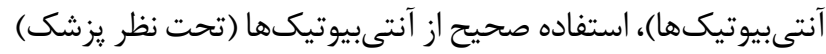
و همجنين عدم مصرف خودسرانه داروها و تركيبات ضد ميكروبى،

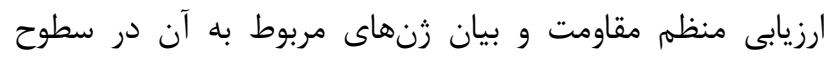
بيمارستانى مىتواند از بروز مشكلات اشاره شده تا حد زيادى بكان بكاهد.

با توجه به شيوع بالاى عفونتهاى بيمارستانى ناشى از

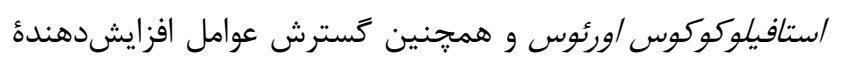

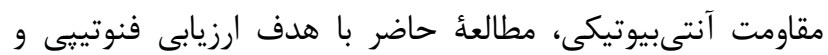
رنوتيبى تشكيل بيوفيلم توسط /ستافيلوكوكوس اورئوسهاى

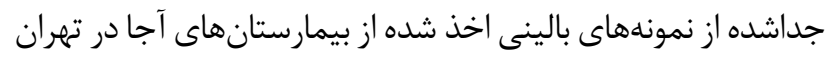
و ارتباط آن با مقاومت ضد ميكروبى انجام كرديد.

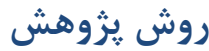

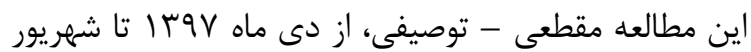

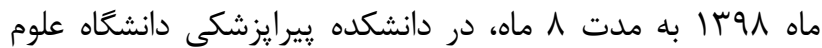

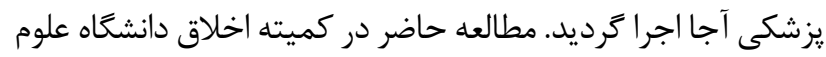

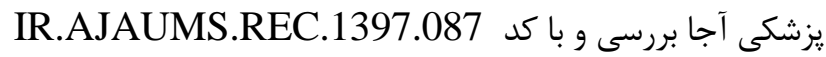
تاييد كرديده است.

با استفاده از فرمول محاسبه حجم نمونه و با توجه به نتايج مطالعات

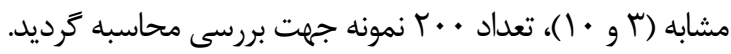

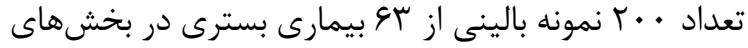
مختلف بيمارستانهاى سطح آجا در تهران جمعآورى برى برديد.

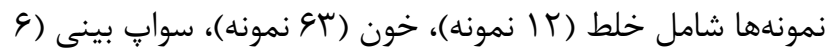

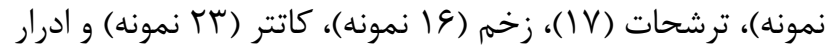

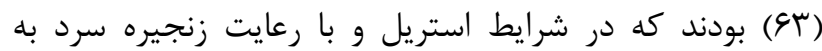

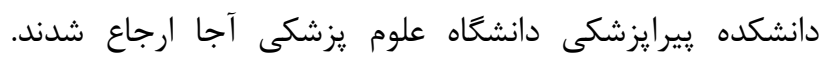

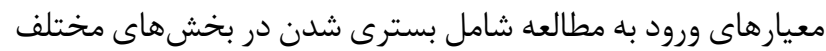

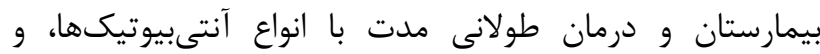
معيارهاى خروج از مطالعه شامل درمان سريايى (عدم بسترى) و و

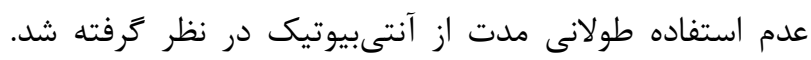
متغيرهاى مورد مطالعه در تحقيق حاضر شامل: حضور التئف

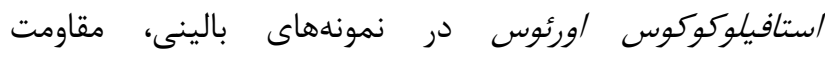

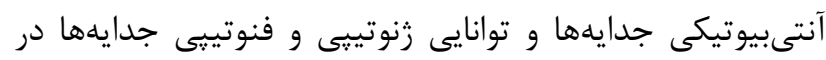

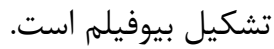

(F). اين باكترى عامل ايجادكننده بسيارى از بيمارىها در انسان، از عفونتهاى يوستى تا عفونتهاى حاد و تهاجمى مانند ينومونى، عفونت بافتهاى نرم، استخوان، دريجههاى قلب و سيتىسمى هاى إنى

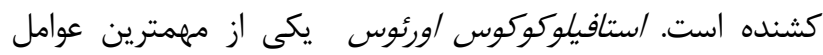

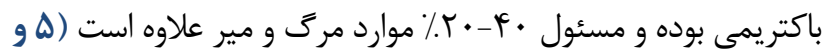

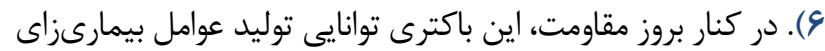
مختلفى از قبيل توكسين، آنتىزنهاى سطحى، آنزيمهاى خارج

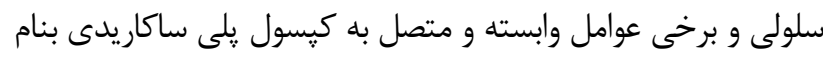

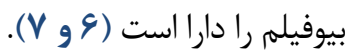

در باكترى /ستافيلوكوكوس /ورئوس نقش بيمارىزا بودن

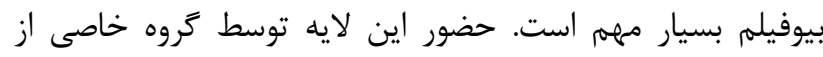

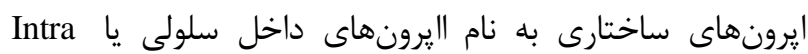
كد مىشود كه داراى لوكوسهاى زنى اخلى إنى

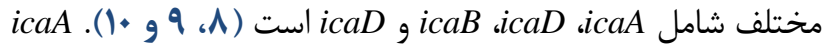
يك القاگر اوليه براى شروع ساخت بيوفيلم در /ستافيلوكوكوس اورئوس است. اين زن با حضور UDP-Nacetylglucosamine فعاليت

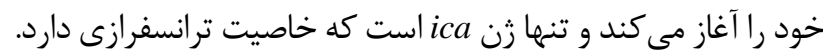
icaD

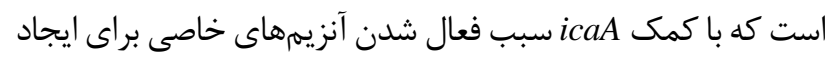

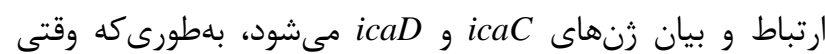

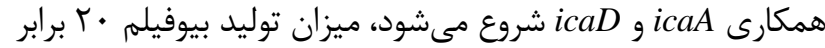
افزايش مىيابد (9 و •l). icaC ارتباط بين فضاى داخلى و خارجى مانى

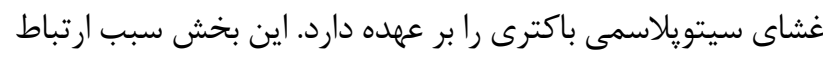

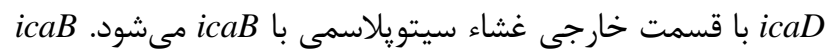
تنها لوكوسى است كه بهصورت خارج سيتويلاسمى قرار ترفته است و ارتباط سطحى باكترى با پِلىساكاريدهاى خسبنده داخل سلولى را حفظ مى كند. يكى از (polysaccharide intercellular adhesion) عواملى كه سبب افزايش ميزان بيان اين ايرونها در /ستافيلوكوكوس

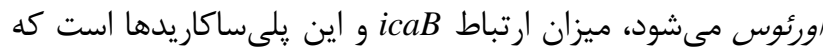

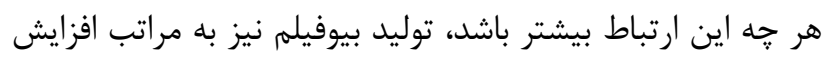

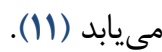

در محيطهاى بيمارستانى بيوفيلم ميكروبى روى سطوح

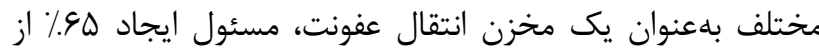

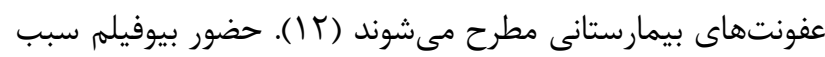
اتصال/ستافيلوكوكوس /ورئوس به كاتترها، سوندهاى ادرارى و ساير ابزارآلات بيمارستانى مىشود كه مىتوانند با آلوده كردن اين سطوح

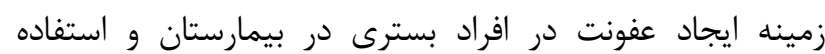


براى بررسى كمى توليد بيوفيلم با روش ميكرويليت

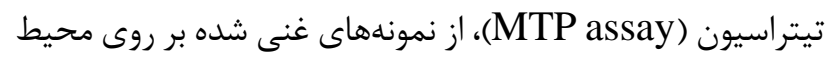

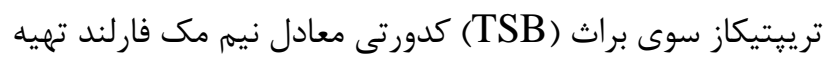

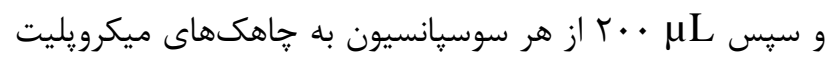

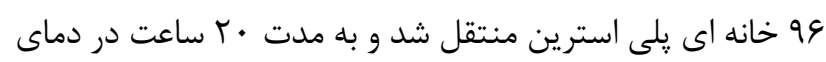

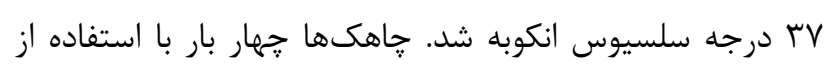

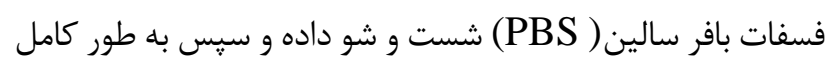

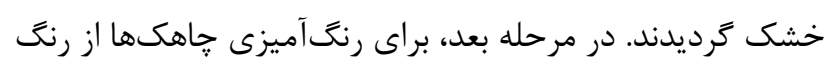

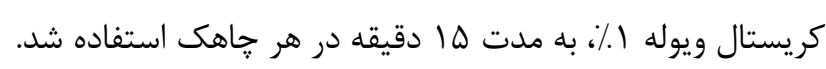

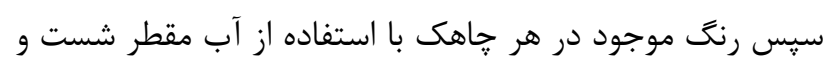

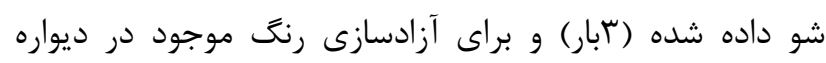

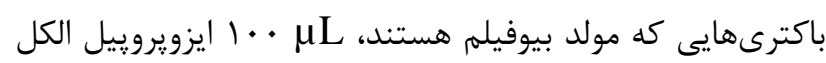

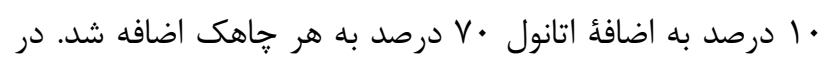

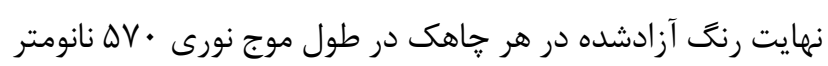

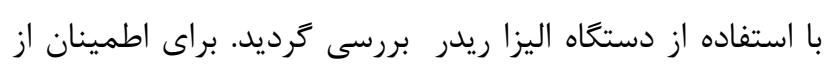

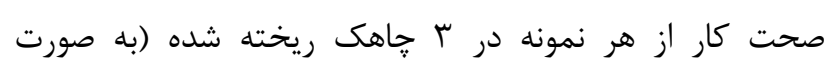

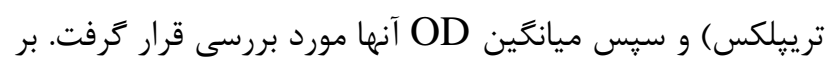

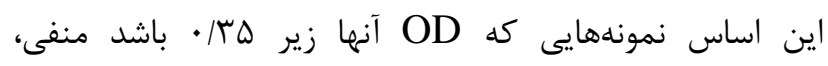

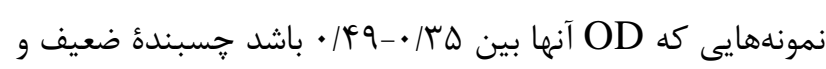

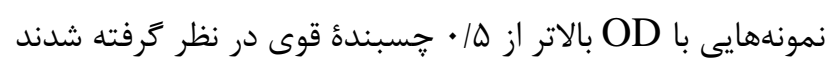
(1) (1). در اين تست از سويه استاندارد /ستافيلوكوكوس اورئوس ATCC 25923 به عنوان كنترل مثبت استفاده شد.

\section{DNA استخراج}

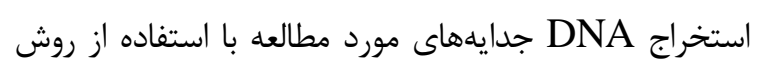

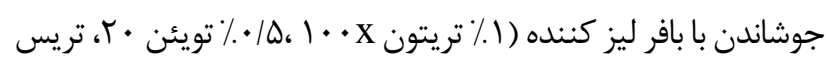

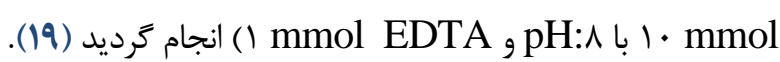

\section{تاييد مولكولى جدايههاى /ستافيلوكوكوس /ورئوس}

براى تأييد مولكولى جدايهها از تكثير زن اختصاصى

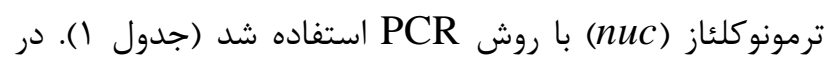

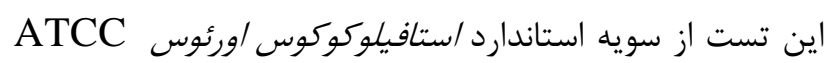

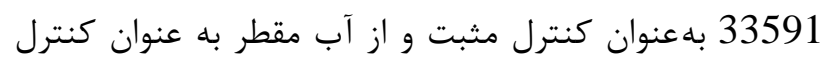

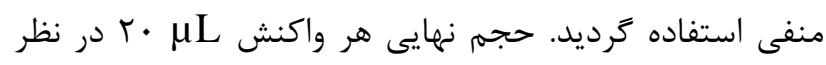

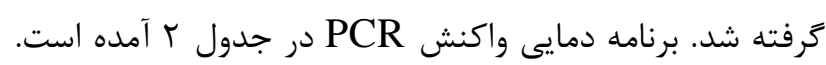
در ادامه محصولات حاصل از PCR با استفاده از زل آكارز

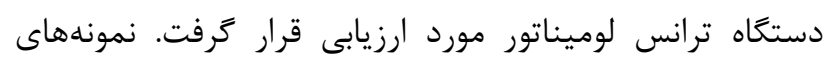

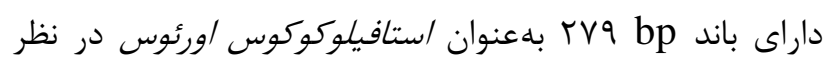

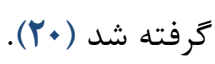

نمونه هاى اخذ شده ابتدا بر روى محيط Blood Agar

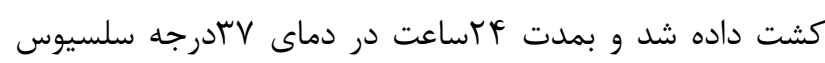

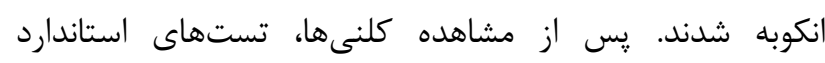

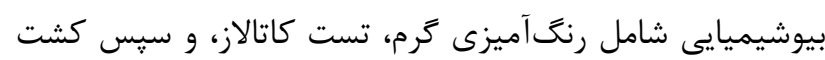

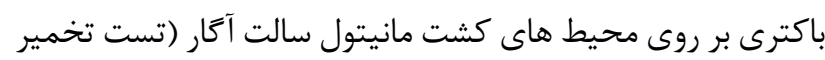

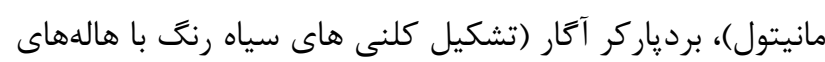

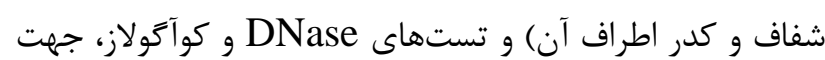
تأييد جدايهها انجام كرفت (If)

\section{ارزيابى حساسيت ضدميكروبى (تعيين الگَوى مقاومت}

آنتى بيوتيكى)

براى انجام اين تست از محيط كشت مولر هينتون آكار و كاني

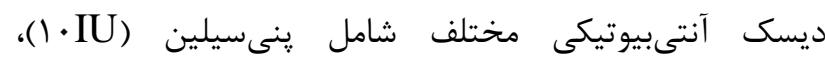
سيبروفلوكساسين (

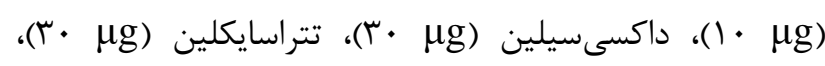

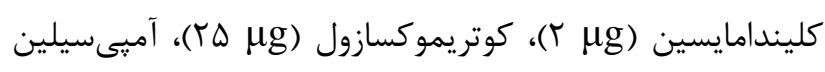

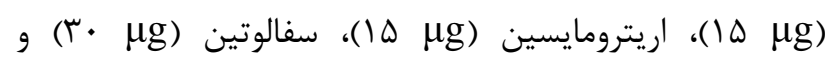

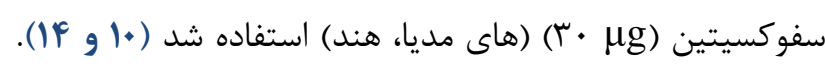

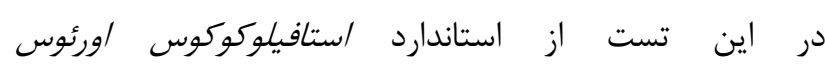

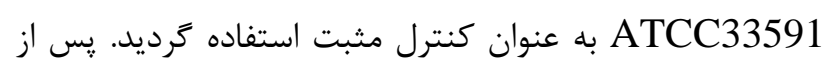

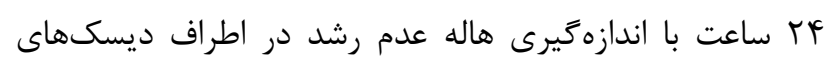

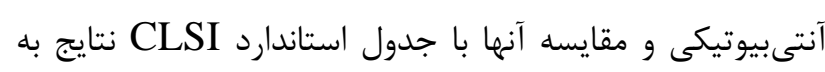

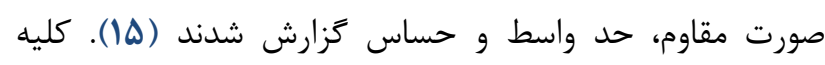

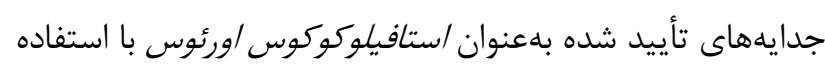

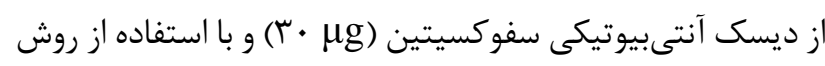

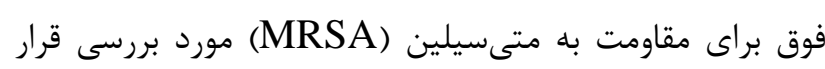

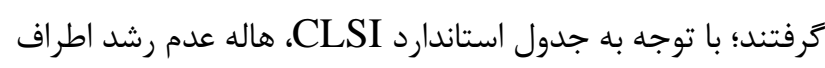

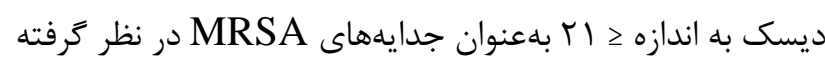

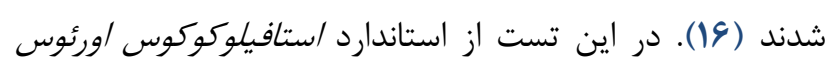
ATCC33591 بهنوان كنترل مثبت استفاده ترديد.

\section{تعيين فنوتيبى سويههاى توليدكنندهُ بيوفيله}

براى شناسايى سويههاى مولد بيوفيلم از روش هاى تست كنَّو

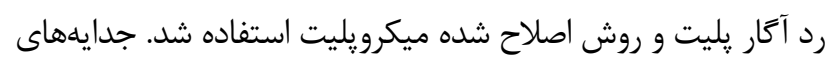

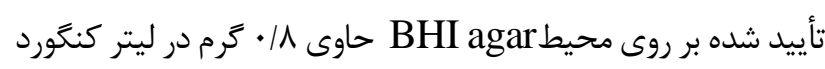

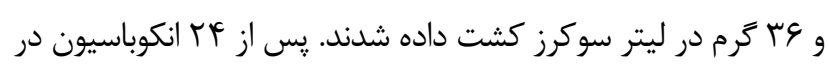

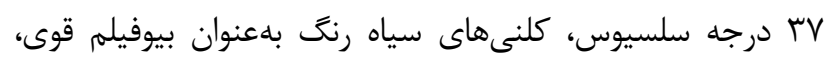

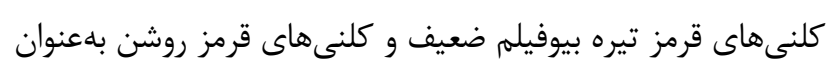
سويههاى بيوفيلم منفى در نظر ترفته شدند (IV) 
هر واكنش ML · r در نظر گرفته شد. برنامهاى دمايى واكنش اين ايرون در جدول r PCR

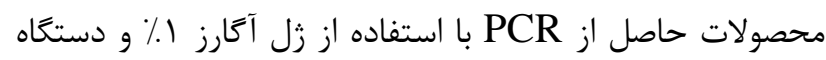

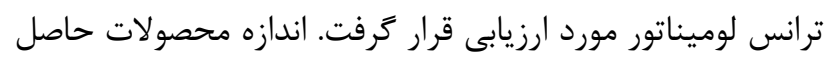

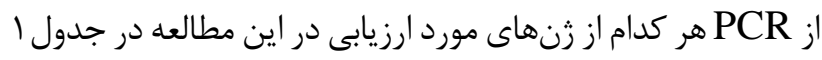

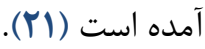

\section{شناسايى مولكولار سويههاى توليد كننده بيوفيله}

براى شناسايى سويههاى مولد بيوفيلم از تكثير زنهاى ايرون (با زنهاى icaABCD PCR

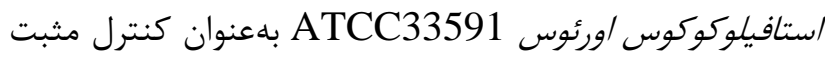
و از آب مقطر بهعنوان كنترل منفى استفاده كرديد. حجم نهايى

جدول ا. يرايمرهاى مورد استفاده در مطالعه (آ؟، • (T)

\begin{tabular}{|c|c|c|}
\hline توالى برايمر & اندازه محصول (bp) & 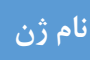 \\
\hline $\begin{array}{c}\text { F: GCGATTGATGGTGATACGGTT } \\
\text { R: AGCCAAGCCTTGACGAACTAAAGC }\end{array}$ & rVq & пис \\
\hline $\begin{array}{l}\text { F: ACACTTGCTGGCGCAGTCAA } \\
\text { R:TCTGGAACCAACATCCAACA }\end{array}$ & 111 & $i c a A$ \\
\hline $\begin{array}{l}\text { F: AGAATCGTGAAGTATAGAAAATT } \\
\text { R: TCTAATCTTTTTCATGGAATCCGT }\end{array}$ & $\Lambda \Lambda$. & $i c a B$ \\
\hline $\begin{array}{l}\text { F: ATGGGACGGATTCCATGAAAAAGA } \\
\text { R: TAATAAGCATTAATGTTCAATT }\end{array}$ & 1.99 & icaC \\
\hline $\begin{array}{c}\text { F: ATGGTCAAGCCCAGACAGAG } \\
\text { R: AGTATTTTCAATGTTTAAAGCAA }\end{array}$ & 191 & $i c a D$ \\
\hline
\end{tabular}

جدول r. برنامه دمايى واكنش PCR براى زنهاى مورد مطالعه (•r سيكل)

\begin{tabular}{|c|c|c|c|c|c|}
\hline \multicolumn{5}{|c|}{ نام مراحل، دما و زمان انجام واكنش PCR } & \\
\hline كسترش نهايى & كَترش & 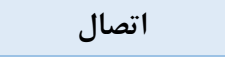 & 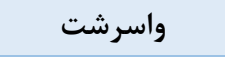 & 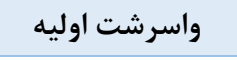 & 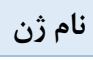 \\
\hline ل V V د. س، • ا دقيقه & 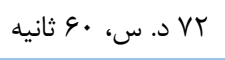 & 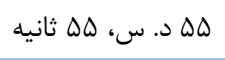 & 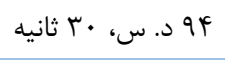 & ا & $N u c$ \\
\hline 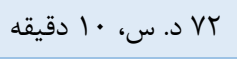 & 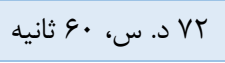 & 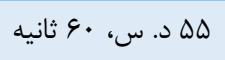 & 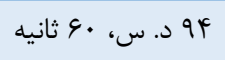 & 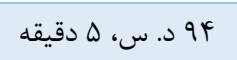 & $i c a A$ \\
\hline ل & 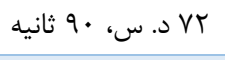 & 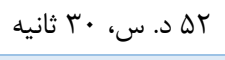 & 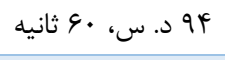 & 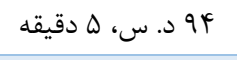 & $i c a B$ \\
\hline r V د. س، • ا دقيقه & r V د. س، • ثانيه & ه د. س، • ب ثانيه & جو د. س، • 9 ثانيه & F & icaC \\
\hline r V د. س، •ا دقيقه & Vr د. س، • • ثانيه & Dه د. س، •• ثانيه & F q د. س، •r ثانيه & זq د. س، ه دقيقه & icaD \\
\hline
\end{tabular}

\section{يافتهها}

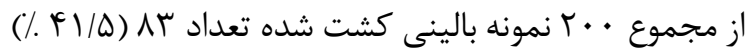

مورد به صورت فنوتييى بهعنوان /ستافيلوكوكوس /ورئوس مشخص بـونى

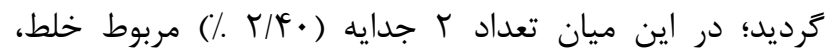

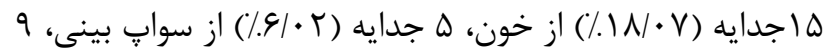

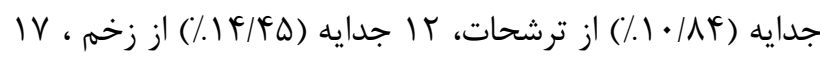

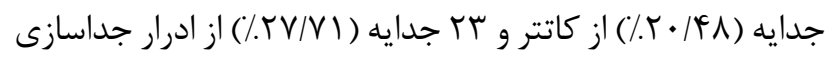
گرديدند، كه در آزمون مولكولى كليه جدايههاى تأييدشده بهصورت فنوتييى، واجد زن اختصاصى nuc بودند (شكل ().

\section{تحليل آمارى}

نتايج بهدستآمده توسط نرم افزاز آمارى SPSS نسخهُ · X². (SPSS Inc., Chicago, IL., USA)

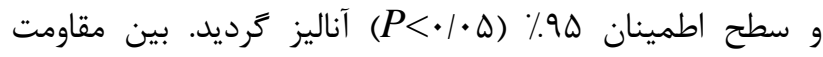
آنتىبيوتيكى با تشكيل بيوفيلم ارتباط آمارى معنىىارى ديده شد.

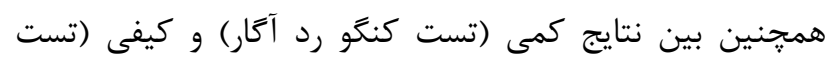
ميكرويلت تيتراسيون) تشكيل بيوفيلم ارتباط آمارى معنى دارى دئ

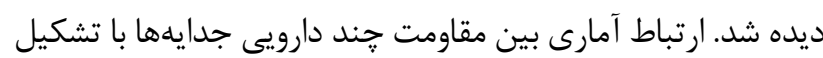
بيوفيلم مشاهده شد و همجنين ارتباط آمارى بين وجود زنهاى بـن

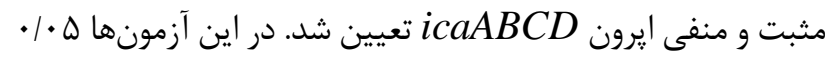
P-value > بهعنوان تفاوت معنى دار آمارى در نظر كرفته شد. 


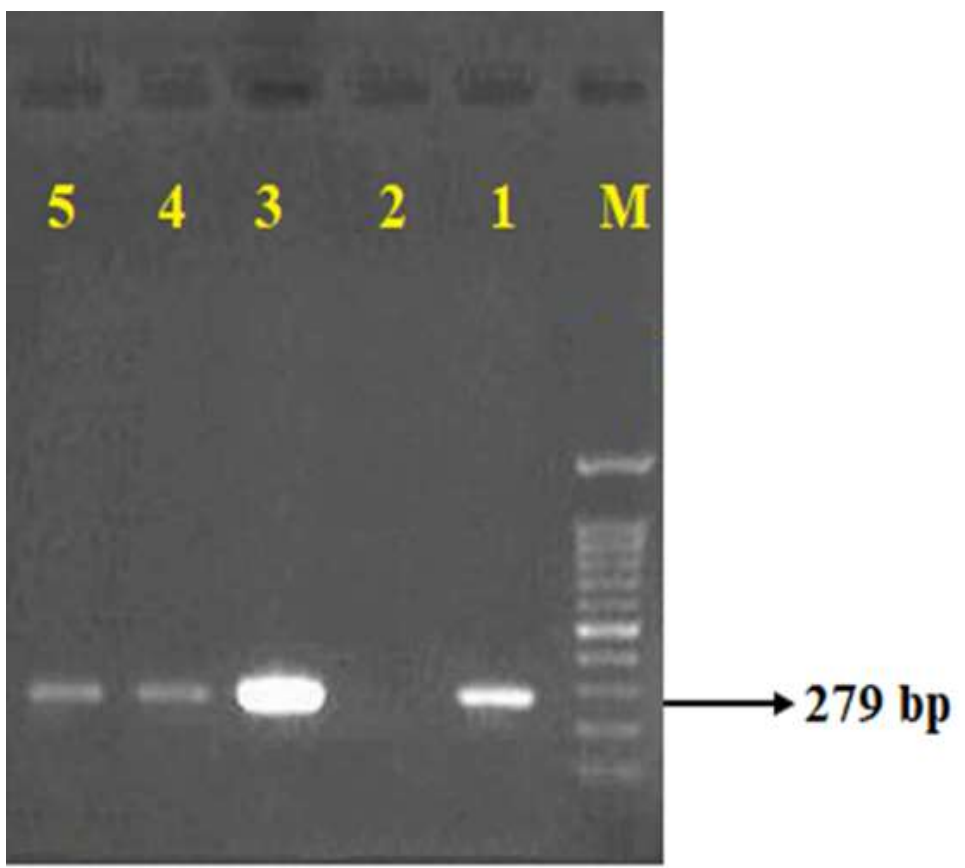

شكل ا. الكتروفورز محصول PCR زن

ستون M- ماركر 100، ستون ا- كنترل مثبت (سويه استاندارد/ستافيلوكوكوس /ورئوس ATCC33591)، ستون r- كنترل منفى (آب مقطر)، ستون هاى بتا هـ نمونهاى مورد مطالعه

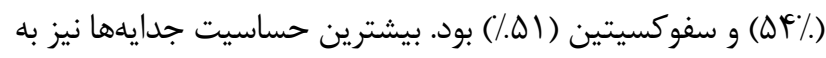

الكوى مقاومت ضد ميكروبى

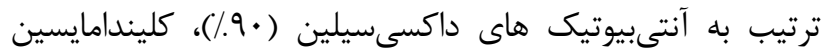

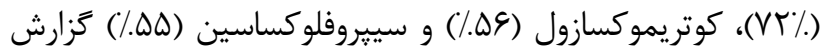

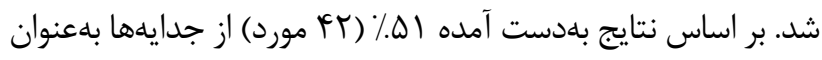

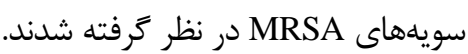

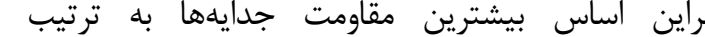

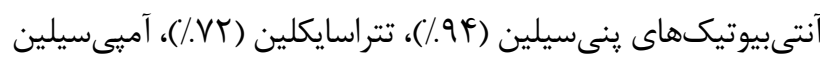

جدول r. فراوانى و درصد مقاومت آنتىبيوتيكى جدايههاى /ستافيلوكوكوس /ورئوس به آنتىبيوتيكهاى مختلف

\begin{tabular}{|c|c|c|c|}
\hline فراوانى و درصد نمونههاى حساس & فراوانى و درصد نمونه هاى حد واسط & فراوانى و درصد نمونههاى مقاوم & نام آنتىبيوتيك \\
\hline$\Delta(\xi \%)$ & - & $\vee \wedge(q ศ \%) *$ & ينىسيلين \\
\hline$\notin \notin(\Delta \Delta \%)$ & $r(r \%)$ & $r \Delta(\kappa r \%)$ & سييروفلوكساسين \\
\hline $\operatorname{Ir}(19 \%)$ & $1 \cdot(1 Y \%)$ & G. (VY\%) & تتراسايكلين \\
\hline$r r(r \Lambda \%)$ & $r F(r 9 \%)$ & rq ( $4 \% \%)$ & 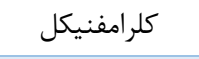 \\
\hline $4 \mid(\$ 9 \%)$ & - & FT $(\Delta) \%)$ & سفوكسيتين \\
\hline$F \Delta(\Delta F \%)$ & $1(1 \%)$ & $r \checkmark(\uparrow \Delta \%)$ & جنتامايسين \\
\hline $\operatorname{RF}(\Delta \Gamma \%)$ & $r(\kappa \%)$ & rष (ศץ\%) & اريترومايسين \\
\hline $\operatorname{FF}(\Delta \Gamma \%)$ & $\operatorname{Ir}(\mid F \%)$ & $r V(r r \%)$ & سفالوتين \\
\hline$r q(r \Delta \%)$ & $9(11 \%)$ & $F \Delta(\Delta F \%)$ & آمبىسيلين \\
\hline G. (VY\%) & - & $r \mu(T \Lambda \%)$ & كليندامايسين \\
\hline$F v(\Delta \%)$ & $f(\Delta \%)$ & $r r(T 9 \%)$ & كوتريموكسازول \\
\hline$V \Delta(9 \cdot \%)$ & $\Delta(8 \%)$ & $r(\kappa \%)$ & داكسى سيلين \\
\hline
\end{tabular}


در تجزيه و تحليل آمارى نتايج با سطح اطمينان هذ9٪، اختلاف

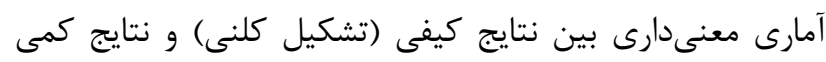

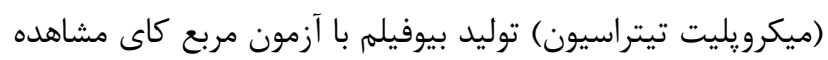

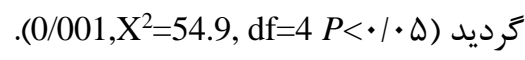

همانطور كه در جدول هـ مشخص شده است، از نظر آمارى اختلاف

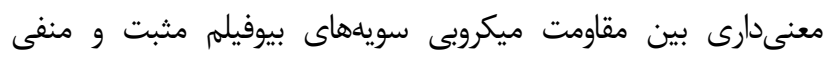

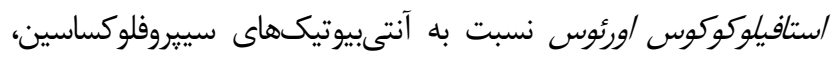

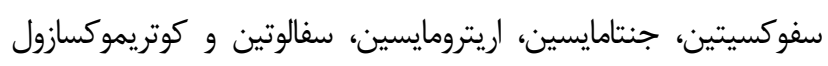

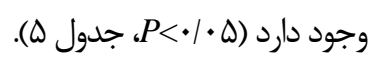

\section{تشكيل بيوفيلم}

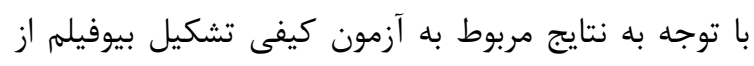

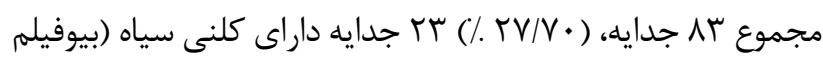

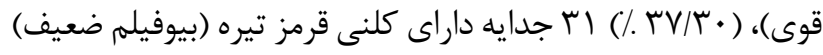

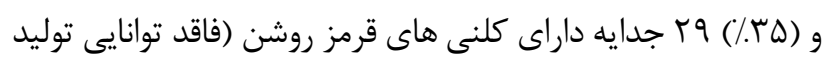

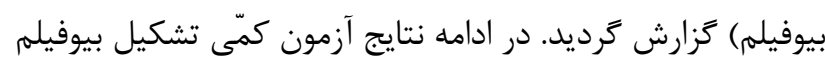

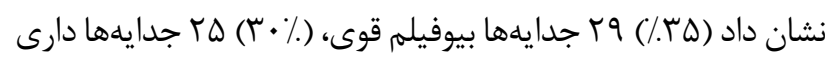

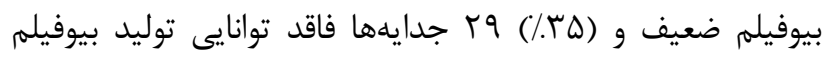

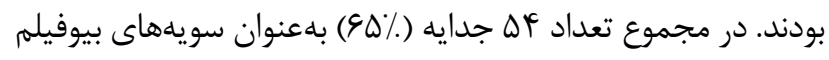

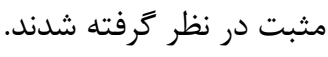

\section{جدول F. مقايسه نتايج تست كمى و كيفى توليد بيوفيلم}

\begin{tabular}{|c|c|c|c|c|}
\hline تست كمى & جسبنده قوى & جسبنده ضعيف & فاقد جسبند & جمع كل \\
\hline كلنىهاى سياه & IV & 4 & - & r \\
\hline كلنىهاى قرمز تيره & ir & 19 & · & r \\
\hline كلنىهاى قرمز روشن & - & - & rq & rq \\
\hline جمع كل & rq & TQ & rq & $\wedge r$ \\
\hline
\end{tabular}

جدولها. مقايسه ميزان مقاومت آنتىبيوتيكى در سويههاى بيوفيلم مثبت و بيوفيلم منفى/ستافيلوكوكوس /ورئوس

\begin{tabular}{|c|c|c|c|}
\hline P-value & فراوانى و درصد سويههاى بيوفيلم منفى (૧ (؟) & $\begin{array}{c}\text { فراوانى و درصد سويه هاى بيوفيلم } \\
\text { مثبت (AF) }\end{array}$ & نام آنتىبيوتيك \\
\hline.$/ 4 \& 0$ & TF (Aץ\%) & $\Delta F(1 \cdots \%) *$ & ينىسيلين \\
\hline$\cdot 1 \cdot$ rs & $r(V /)$. & r & سييروفلوكساسين \\
\hline$\cdot / 1 \wedge \Delta$ & 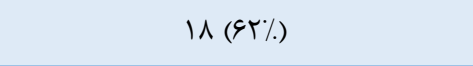 & $\operatorname{Fr}(\vee \wedge \%)$ & تتراسايكلين \\
\hline$\cdot 1 \Delta \cdot \Delta$ & $\|(\Upsilon \wedge \%)$ & $r \Delta(\kappa \& \%)$ & كلر امفنيكل \\
\hline$\cdot / \cdot v$ & $r(V /)$. & $f \cdot(V \psi \%)$ & سفوكسيتين \\
\hline$\cdot \cdot r r$ & - & $r V(1 \cdots \%)$ & جنتامايسين \\
\hline$\cdot 1 \cdot r r$ & - & re $(1 \ldots \%)$ & اريترومايسين \\
\hline$\cdot / \cdot r$ & - & $r V(1 \cdots \%)$ & سفالوتين \\
\hline . IFTV & $\operatorname{If}(\boldsymbol{F} \wedge \%)$ & $\mu$ ( $(\Delta V /)$ & آميىسيلين \\
\hline • & $9(Y) \%)$ & $\mid V(Y \mid \%)$ & كليندامايسين \\
\hline$\cdot / \cdot r$ & - & r & كوتريمو كسازول \\
\hline- & $1(r \%)$ & $r(r \%)$ & داكسىسيلين \\
\hline
\end{tabular}


سويههاى بيوفيلم مثبت و بيوفيلم منفى /ستافيلوكوكوس /ورئوس با

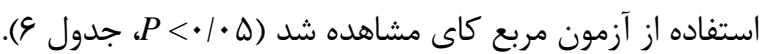
از ميان سويههاى بيوفيلم مثبت تعداد بF جدايه (FF/F) MRSA بودند؛ كليه جدايههاى بيوفيلم منفى حساس به متىسيلين

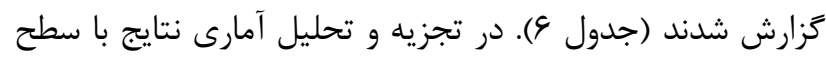

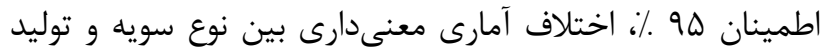
بيوفيلم با آزمون مربع كاى مشاهده ترديد ( .(0/001, $\mathrm{X}^{2}=108.1, \mathrm{df}=3$
در مقايسه مقاومت جنددارويى و مقاومت به متىسيلين در

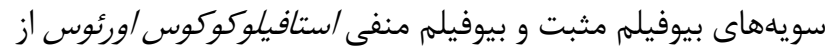

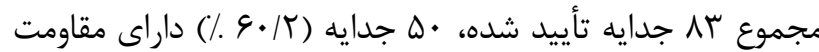
جنددارويى بود. از مجموع QF جدايه بيوفيلم مثبت، تعداد FV جل جدايه

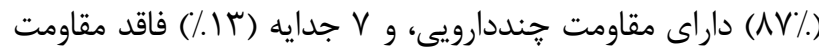

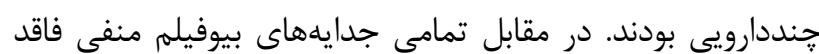
توان مقاومت جنددارويى بودند (جدول \&). از نظر مقاومت

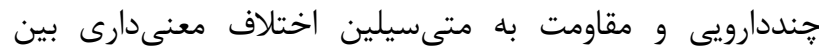

جدول צ. مقايسه مقاومت جֶند دارويى و مقاومت به متىسيلين در سويههاى بيوفيلم مثبت و بيوفيلم منفى /ستافيلوكوكوس /ورئوس

\begin{tabular}{|c|c|c|c|c|}
\hline درصد و فراوانى MSSA & درصد و فراوانى MRSA & $\begin{array}{c}\text { درصد و فراوانى سويههاى } \\
\text { non-MDR }\end{array}$ & $\begin{array}{c}\text { درصد و فراوانى سويههاى } \\
\text { MDR }\end{array}$ & نوع سويه \\
\hline$r \cdot(\Delta \varphi \%)$ & $\operatorname{TF}(F \mathcal{F} \%)$ & $V(\mid r \%)$ & $\mathcal{F V}(\wedge \vee \%)$ & بيوفيلم مثبت (DF) \\
\hline rq $(1 \cdots \%)$ & $\cdot(\cdot)$ & $r q(1 \cdots \%)$ & $\cdot(\cdot)$ & بيوفيلم منفى (Y) \\
\hline$\Delta 9(V 1 \%)$ & $T F(Y q \%)$ & एद (Fт\%) & $F V(\Delta V \%)$ & جمع كل (r) \\
\hline
\end{tabular}

مطالعه زنهاى icaA و icaD است. از مجموع rم جدايه، تعداد •ه جدايه

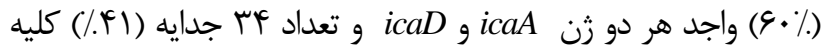
رنهاى ايرون را ica دارا بودند. از نظر آمارى اختلاف معنى دارى بين حضور زنهاى ايرون ica با يكديكر در جدايههاى /ستافيلوكوكوس اورئوس در سطح اطمينان ه9 ٪ وجود نداشت.

\section{بررسى مولكولى ايرون icaABCD}

در بررسى مولكولى ايرون icaABCD، فراوانى حضور زن icaA

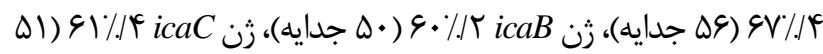

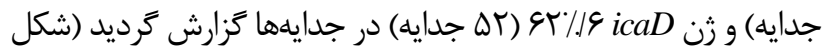
ץ). بر اين اساس شايعترين رن كدكننده توليد بيوفيلم در جدايههاى مورد

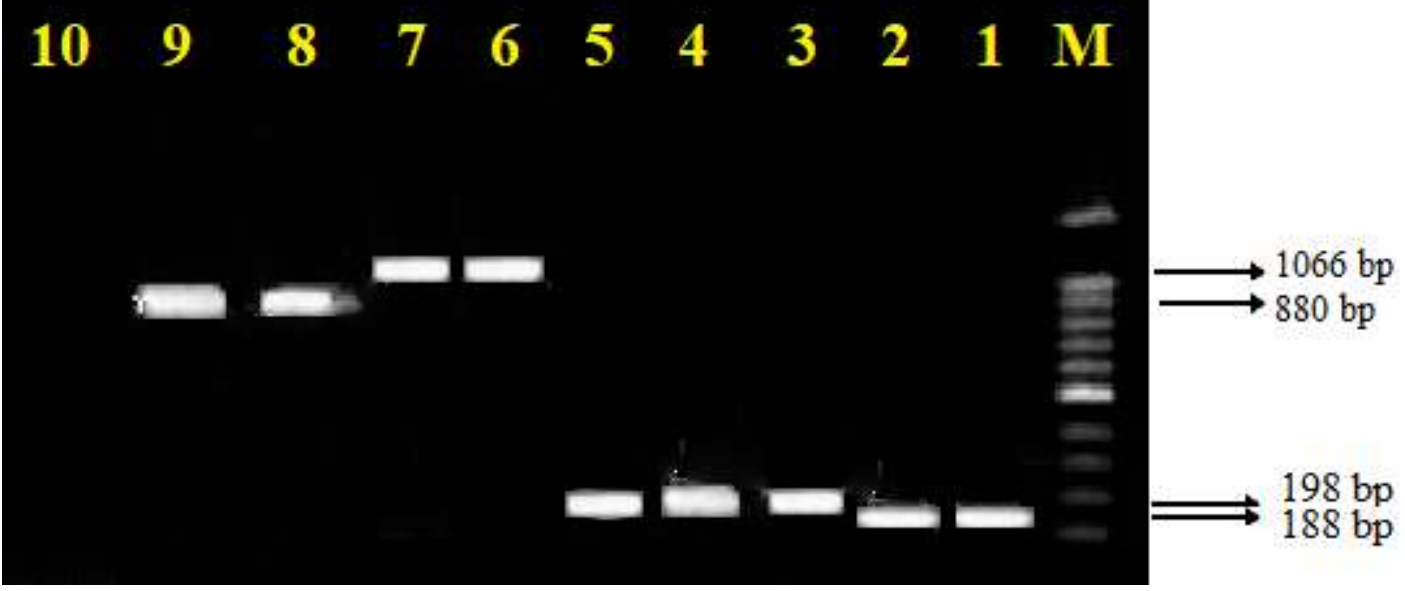

شكل r. نتايج الكتروفورز محصولات PCR زنهاى إيرون ica.

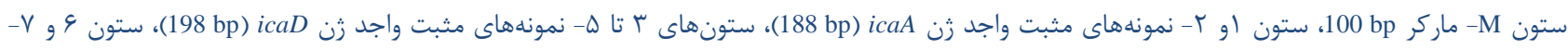

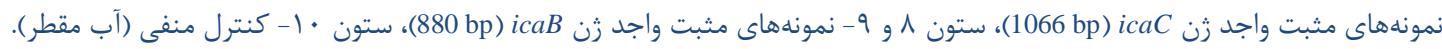




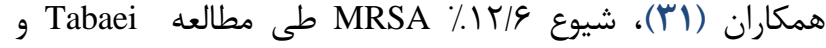

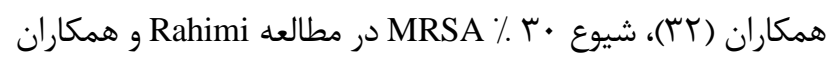

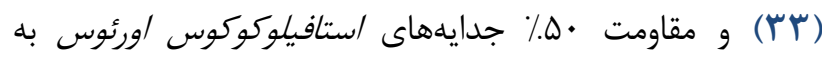

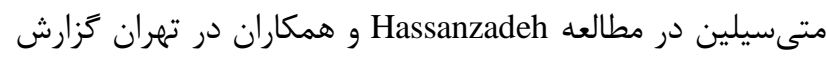

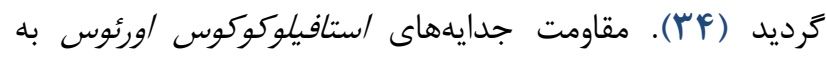

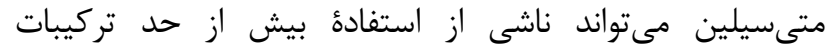

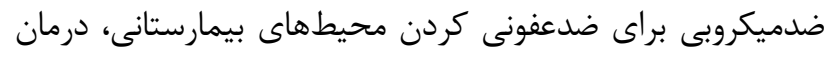

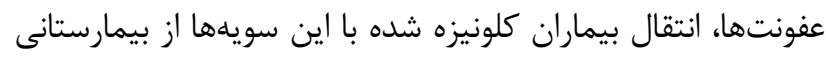

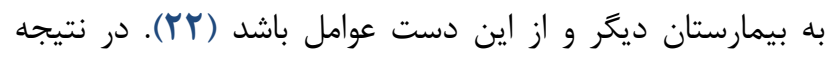

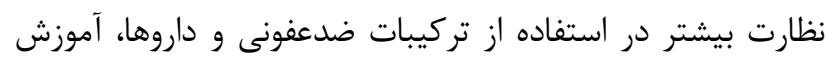

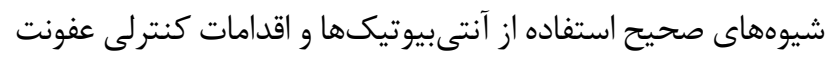
در تمامى بخشهاى بيمارستانها ضرورى است.

مطالعات متعددى در خصوص الگوى مقاومت آنتىبيوتيكى

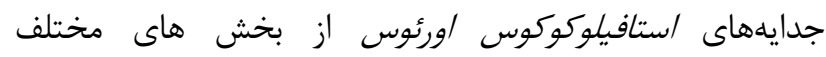

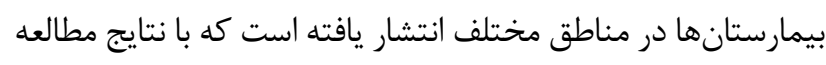

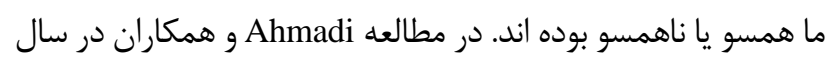

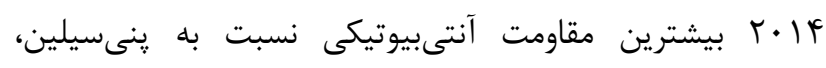

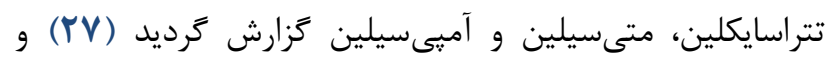
همجنين در مطالعه Hatefizade و همكاران در تهران دئسين در سال

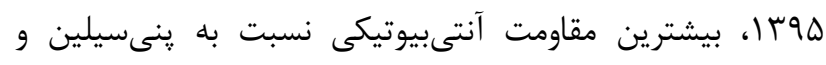

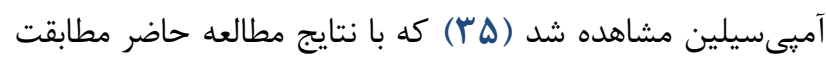

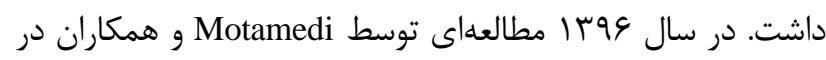

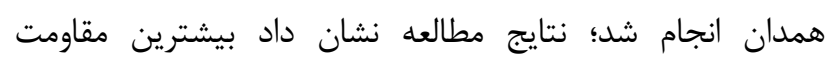

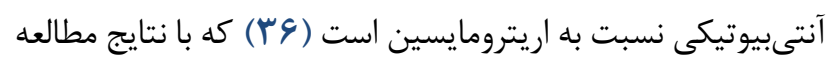

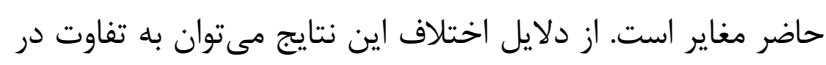

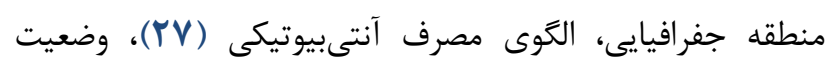
بهداشتى بخشهاى مختلف بيمارستانى (MF) و همرنينين ايجاد مقاومتهاى كروموزومى طى توليد نسل و يا انتقال فاكتورهاى مقاومت بين گونهاى باكتريايى (ع) (ب)، اشاره كرد.

در مطالعأ حاضر علاوه بر تأكيد بر كسترش مقاومت جند

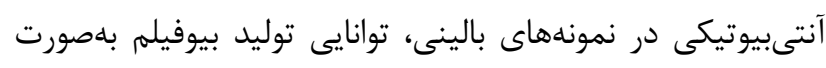

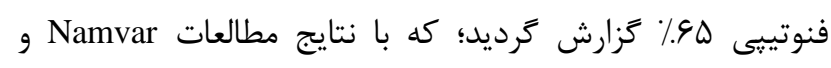

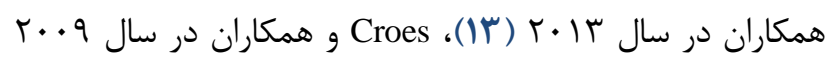

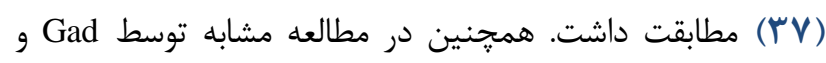

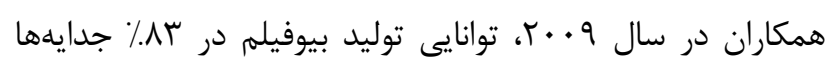

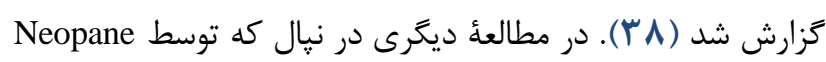

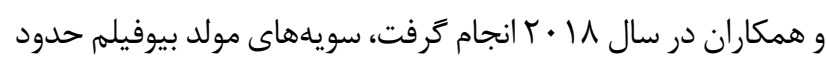

بحث

بر اساس نتايج مطالعه حاضر شيوع /ستافيلوكوكوس /ورئوس

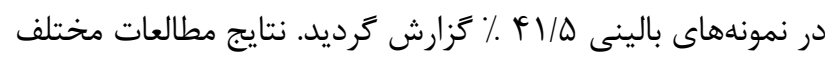

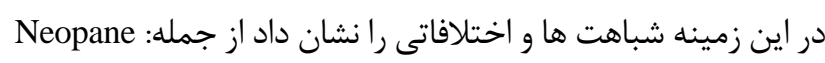

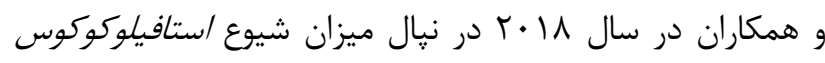

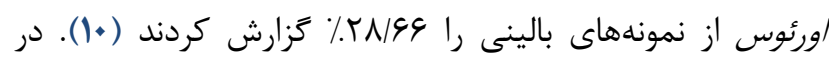

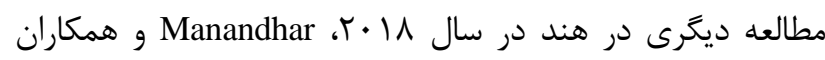

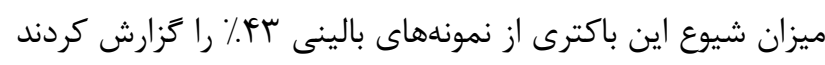

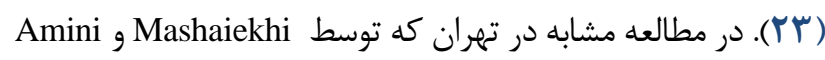

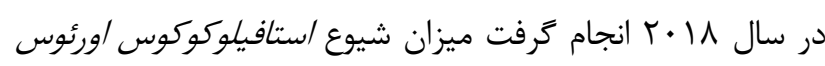

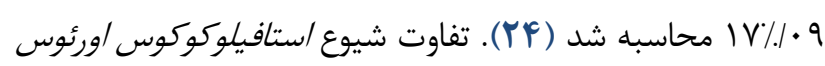

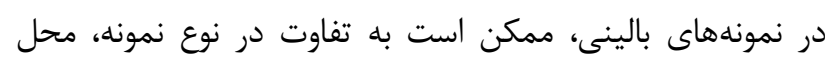

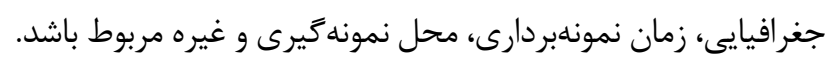
با توجه به نتايج حاصل از تست آنتىبيوكرام در مطالعه حاضر،

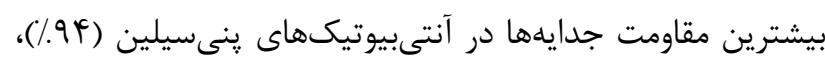

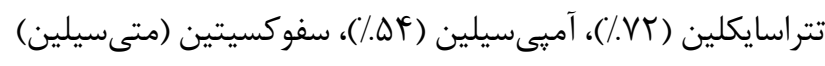

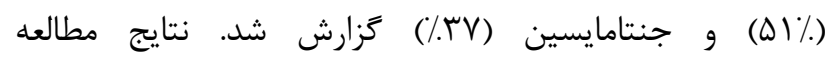
Momtaz Nourbakhsh

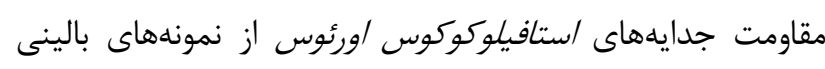

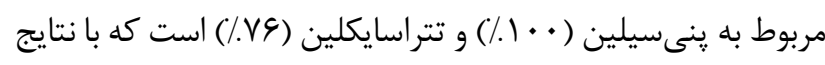

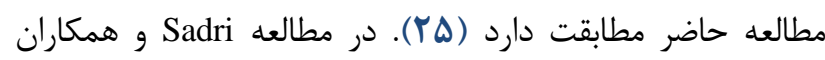

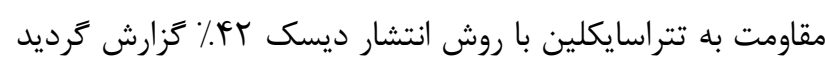

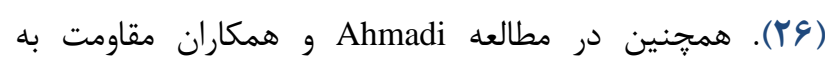

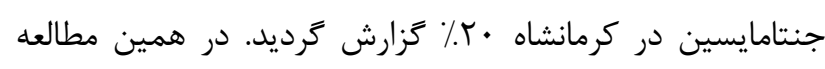

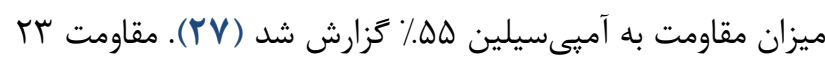

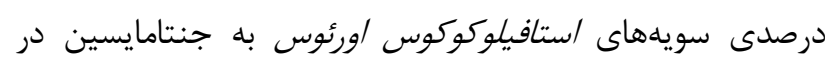

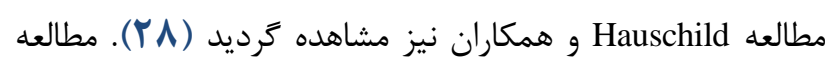
Mirzaee

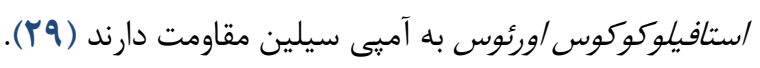
بررسى هاى مطالعه حاضر نشاندهنده شيوع بالاى سويههاى MRSA

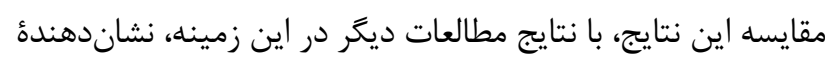

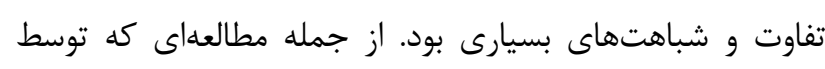
Abdollahi

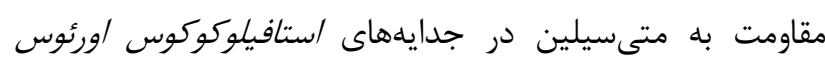

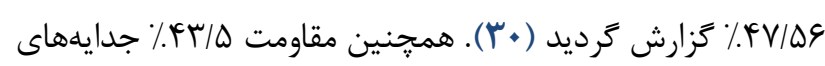

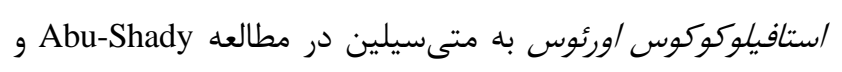




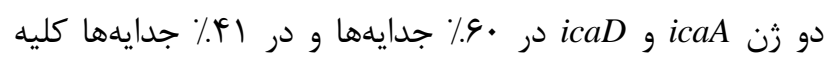
زنهاى ايرون ica مشاهده شد اما جدايهها در تشكيل بيوفيلم بين طيف بيوفيلم قوى و ضعيف قرار كرفتند ولى هيجكدام از جدايهها با

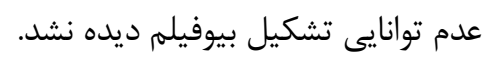

$$
\text { نتيجه كيرى }
$$

براساس نتايج مطالعه حاضر، جدايههاى /ستافيلوكوكوس

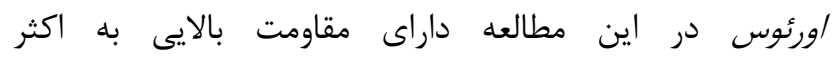
آنتىبيوتيكهاى مورد مطالعه (به ويزه متىسيلين) بودند. همجنين فراوانى قابل توجه زنهاى مولد بيوفيلم در جدايهها مى تواند در افزايش مقاومت جند باكترى در محيط بهخصوص محيطهاى بيمارستانى موثر باشد. در اين مطالعه، از نظر آمارى ارتباط معنى دارى بئ بين ايجاد بيوفيلم و مقاومت آنتىبيوتيكى وجود داشت. حضور زنهاى ايجاد بيوفيلم و نقش آنها در ايجاد مقاومت آنتىبيوتيكى مىتواند عواقبى همجيون بسترى شدن طولانى مدت در بيمارستان، افزايش هزينهاى

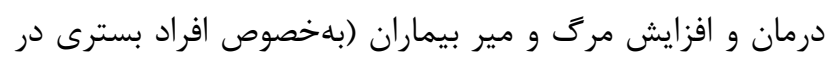

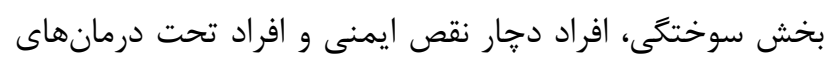

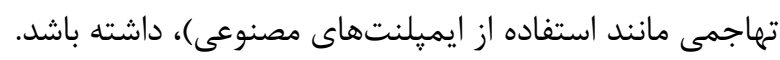

$$
\text { سياسگزارى }
$$

نويسندگان اين مقاله مراتب تشكر و قدردانى خود را از معاونت محترم يزوهشى دانشعاه علوم يزشكى آجا و يرسنل محترم بيمارستانهاى آجا در تهران، ابراز معىنمايند.

$$
\text { تعارض در منافع }
$$

اين مقاله يزوهشى مستقل است كه بدون حمايت مالى إنى سازمانى انجام شده است. در انجام مطالعهُ حاضر، نويسندكان معان هيجزَّه تضاد منافعى نداشتهاند.

\section{Referance}

1. Foster TJ, O'Reilly M, Patel AH, Bramley AJ. Genetic studies of Staphylococcus aureus virulence factors. Antonie Van Leeuwenhoek. 1988; 54(5): 475-82. [DOI:10.1007/BF00461866] [PMID]

2. Oyama T, Miyazaki M, Yoshimura M, Takata T, Ohjimi H, Jimi S. Biofilm-Forming Methicillin-resistant Staphylococcus aureus Survive in Kupffer Cells and Exhibit High Virulence in Mice. Toxins. 2016;8(7):198. [DOI:10.3390/toxins8070198] [PMID] [PMCID]

3. Rahimi F, Katouli M, Karimi S. Biofilm production among methicillin resistant Staphylococcus aureus strains
٪ • بودند ( • (1). عوامل مختلفى مى تواند در تشكيل بيوفيلم موثر باشد، از جمله فاكتورهاى محيطى (مانند قندها، يا يروتئازهاى موجود در محيط رشد،)، در دسترس بودن مواد مغذى، منشاء جغرافيايى، نوع نمونه، سطح ناحيه (خشن يا صاف)، تخلخل، استرسهاى محيطى (مثل در معرض آنتىبيوتيك قرار گرفتن)، خصوصيات جسبندگى سطحى و آرايش زنتيكى باكترى. علاوه بر

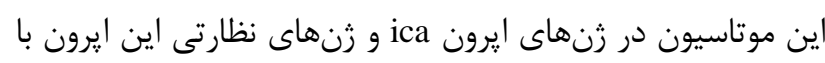

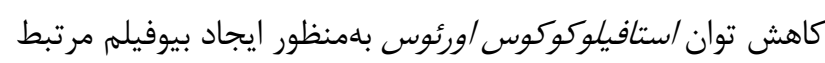

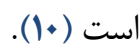

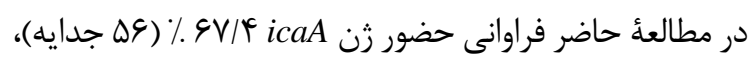

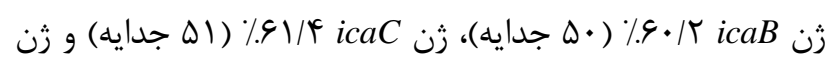

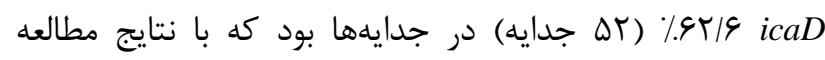
Nourbakhsh

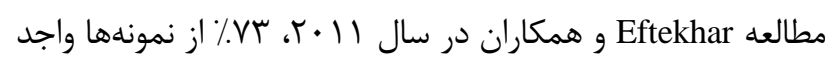

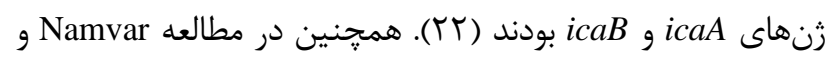

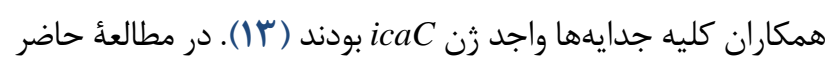

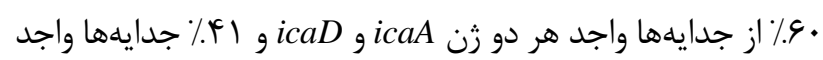

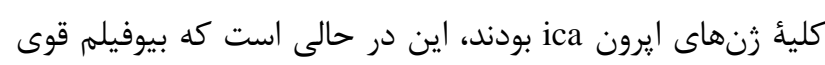

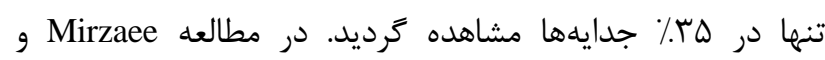

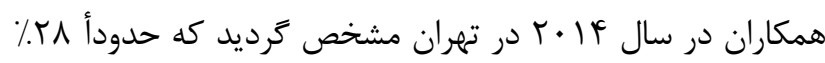

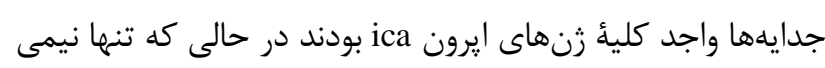
از اين جدايهها توان تشكيل بيوفيلم قوى را داشتند ( (؟). در مطالعة Mashaiekhi استافيلوكوكوس اورئوس واجد هر دو زن icaA و icaD بودند (YF). در بررسى حضور زنها و تشكيل بيوفيلم به صورت فنوتييى در

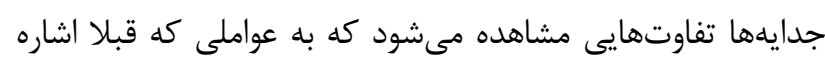

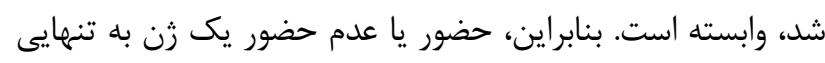

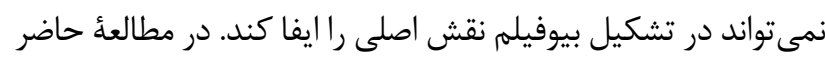

isolated from catheterized patients with urinary tract infection. Microb Pathog. 2016;98:69-76. [DOI:10.1016/j.micpath.2016.06.031] [PMID]

4. Shahmohammadi MR, Nahaei MR, Akbarzadeh A, Milani M. Clinical test to detect mecA and antibiotic resistance in Staphylococcus aureus, based on novel biotechnological methods. Artif Cell Nanomed B. 2016;44(6):1464-8.

[DOI:10.3109/21691401.2015.1041639] [PMID]

5. Becker K, Denis O, Roisin S, Mellmann A, Idelevich EA, Knaack D, et al. Detection of mecA- and mecC-Positive 
Methicillin-Resistant Staphylococcus aureus (MRSA) Isolates by the New Xpert MRSA Gen 3 PCR Assay. J Clin Microbiol. 2016; 54(1): 180-4. [DOI:10.1128/JCM.02081-15] [PMID] [PMCID]

6. Havaei SA, Assadbeigi B, Esfahani BN, Hoseini NS, Rezaei N, Havaei SR. Detection of mecA and enterotoxin genes in Staphylococcus aureus isolates associated with bovine mastitis and characterization of Staphylococcal cassette chromosome mec (SCCmec) in MRSA strains. Iran J Microbiol. 2015; 7(3): 161-7.

7. Federman C, Ma C, Biswas D. Major Components of Orange Oil Inhibit Staphylococcus aureus Growth and Biofilms Formation, and Alter Its Virulence Factors. J Med Microbiol. 2016; 65(7): 688-695. [DOI:10.1099/jmm.0.000286] [PMID]

8. Thilakavathy P, Priyan RM, Jagatheeswari PA, Charles J, Dhanalakshmi V, Lallitha S, et al. Evaluation of Ica Gene in Comparison with Phenotypic Methods for Detection of Biofilm Production by Coagulase Negative Staphylococci in a Tertiary Care Hospital. J Clin Diagn Res. 2015; 9(8): 16-9. [DOI:10.7860/JCDR/2015/11725.6371] [PMID] [PMCID]

9. Tyner H, Patel R. Propionibacterium acnes biofilm - A sanctuary for Staphylococcus aureus. Anaerobe. 2016; 40: 63-7. [DOI:10.1016/j.anaerobe.2016.05.014] [PMID]

10. Neopane P, Prasad Nepal H, Shrestha R, Uehara O, Abiko Y. In Vitro Biofilm Formation by Staphylococcus aureus Isolated From Wounds of Hospital-admitted Patients and Their Association With Antimicrobial Resistance. Int. J Gen Med. 2018; 11: 25-32.

[DOI:10.2147/IJGM.S153268] [PMID] [PMCID]

11. Costa MO, Beltrame CO, Ferreira FA, Botelho AM, Lima NC, Souza RC, et al. Complete Genome Sequence of a Variant of the Methicillin-Resistant Staphylococcus aureus ST239 Lineage, Strain BMB9393, Displaying Superior Ability to Accumulate ica-Independent Biofilm. Genome Announc. 2013;1(4).

[DOI:10.1128/genomeA.00576-13] [PMID] [PMCID]

12. Naicker PR, Karayem K, Hoek KG, Harvey J, Wasserman E. Biofilm Formation in Invasive Staphylococcus aureus Isolates is Associated With the Clonal Lineage. Microb Pathog. 2016; 90: 41-9.

[DOI:10.1016/j.micpath.2015.10.023] [PMID]

13. Namvar AE, Asghari B, Ezzatifar F, Azizi G, Lari AR. Detection of the Intercellular Adhesion Gene Cluster (ica) in Clinical Staphylococcus aureus Isolates. GMS Hyg Infect Control. 2013; 8(1): 03.

14. Murray PR, Rosenthal KS, Pfaller MA. Medical Microbiology E-Book. Elsevier Health Sciences; 2020 Apr 26.

15. Pa W. Clinical and Laboratory Standard Institute C. Methods for Dilution Antimicrobial Susceptibility Tests for Bacteria That Grow Aerobically Approved Standard M7-A7 Clinical and Laboratory Standard Institute. 2006.
16. Doebbeling B. The Epidemiology of Methicillin-resistant Staphylococcus aureus Colonisation and Infection. J Chemother. 1995; 7(3): 99-103.

17. Silva G, Kantzanou M, Justice A, Massey RC, Wilkinson AR, Day N, Peacock SJ. The ica Operon and Biofilm Production in Coagulase- Negative Staphylococci Associated with Carriage and Disease in a Neonatal Intensive Care Unit. J Clin Microbiol. 2002; 40(2): 382-8. [DOI:10.1128/JCM.40.02.382-388.2002] [PMID] [PMCID]

18. Christensen GD, Simpon WA, Younger JJ, Baddour LM, Barrett FF, Meleton DM, et al. Adherence of CoagulaseNegative Staphylococci to Plastic Tissue Culture Plates: a Quantitative Model for the Adherence of Staphylococci to Medical Devices. J Clin Microbiol. 1985; 22(6): 9961006. [DOI:10.1128/JCM.22.6.996-1006.1985] [PMID] [PMCID]

19. Udo R, Hans-Jörg L, Michaela M, Birgit L, Norbert L. Rapid Identification of Methicillin-Resistant Staphylococcus aureus and Simultaneous Species Confirmation Using Real-Time Fluorescence PCR. J. $\begin{array}{llll}\text { Clin. } & \text { Microbiol. } 2000 \quad 38(6): \quad 2429-2433 .\end{array}$ [DOI:10.1128/.38.6.2429-2433.2000] [PMID] [PMCID]

20. Zhang K, Sparling J, Chow BL, Elsayed S, Hussain Z, Church DL, et al. New Quadriplex PCR Assay for Detection of Methicillin and Mupirocin Resistance and Simultaneous Discrimination of Staphylococcus aureus from Coagulase-negative Staphylococci. Journal of Clinical Microbiology. 2004; 42(11): 4947-55. [DOI:10.1128/JCM.42.11.4947-4955.2004] [PMID] [PMCID]

21. Piechota M, Kot B, Frankowska-Maciejewska A, Grużewska A, Woźniak-Kosek A. Biofilm formation by methicillin-resistant and methicillin-sensitive Staphylococcus aureus strains from hospitalized patients in Poland. Biomed Res. Int. 2018 Dec 27;2018. [DOI:10.1155/2018/4657396] [PMID] [PMCID]

22. Eftekhar F, Dadaei T. Biofilm Formation and Detection of icaAB Genes in Clinical Isolates of Methicillin Resistant Staphylococcus aureus. Iran J Basic Med Sci. 2011; 14(2):132-6.

23. Manandhar S, Singh A, Varma A, Pandey S, Shrivastava N. Evaluation of methods to detect in vitro biofilm formation by staphylococcal clinical Isolates. BMC Res Notes. 2018; 11: 714. [DOI:10.1186/s13104-018-3820-9] [PMID] [PMCID]

24. Mashaiekhi S, Amini K. Antibiotic resistance pattern and biofilm production in Staphylococcus aureus isolates and Staphylococcus epidermidis isolated from hospital infections Tehran in 2016. J Birjand Uni Med Sci. 2018; 25(2): 160-166.

25. Nourbakhsh F, Momtaz H. Evaluation of Phenotypic and Genotypic Biofilm Formation in Staphylococcus aureus Isolates Isolated from Hospital Infections in Shahrekord, 2015. AMUJ. 2016; 19(109): 69-79. 
26. Sadri H, Owlia P, Shahrbanooie R. Vancomycin resistance among clinical isolates of Staphylococcus aureus. Arch Iranian Med. 2005; 8(2): 100-103.

27. Ahmadi Z, Tajbakhsh E, Momtaz H. Detection of the antibiotic resistance pattern in Staphylococcus aureus isolated from clinical samples obtained from patients hospitalised in Imam Reza hospital, Kermanshah. J Microb World. 2014; 6(4): 299-311.

28. Hauschild T, Sacha P, Wieczorek P, Zalewska M, Kaczyñska K, Tryniszewska E. Aminoglycosides resistance in clinical isolates of Staphylococcus aureus from a University Hospital in Bialystok, Poland. Folia Histochem Cytobiologica. 2008; 46(2): 225-228. [DOI:10.2478/v10042-008-0034-3] [PMID]

29. Mirzaee M, Najar-Peerayeh S, Behmanesh M, Forouzandeh Moghadam M, Ghasemian AM. Biofilm Formation and Presence of ica Genes in Staphylococcus aureus Isolated from Intensive Care Unit. J Mazandaran Univ Med Sci. 2014; 24(115): 43-51.

30. Abdollahi A, Kouhpaye SA, Najafipour S, Mansouri Y, Abdollahi Kherabadi S, Jafari S. Frequency of drug resistance and staphylococcal chromosomal cassette mec (SCCmec). Genotype in Methicillin-Resistant Staphylococcus aureus strains. Behdad, Scientific and Research Journal of Alborz Medical Sciences. 2012;1(1):47-52.

31. Abu-Shady HM, El-Essawy AK, Salama MS, El-Ayesh AM. Detection and molecular characterization of vancomycin resistant Staphylococcus aureus from clinical isolates. African J of Biotech. 2012; 11(99): 494-503.

32. Tabaei S, Noghondar MK, Mohammadzadeh M, Ataei L, Amel Jamehdar S. Pattern of antibiotic resistance in methicillin-resistant Staphylococcus aureus (MRSA) strains isolated from clinical specimens: Imam Reza hospital in Mashhad. Med J Mashhad Uni Med Sci. 2016; 59(2): 64-70.

33. Rahimi F, Bouzari M, Katouli M, Pourshafie MR. Antibiotic resistance pattern of methicillin resistant and methicillin sensitive staphylococcus aureus isolates in Tehran, Iran. Jundishapur J Microbiol. 2013; 6:144-149. [DOI:10.5812/jjm.4896]

34. Hassanzadeh S, Pourmand MR, Hadadi A, Nourijeylani K, Yousefi M, Mashhadi R. Frequency and antimicrobial resistance patterns of methicillin resistant staphylococcus aureus in Tehran. J Med Bacteriol. 2013; 2: 41-46.
35. Hatefizade B, Hosseini F, Moradi Bidhendi S. Study of some of antiseptic drugs on Staphylococcal strains biofilm isolated from patients with infectious skin during 20142015 in Tehran city. Razi J Med Sci. 2016; 23(148): 128135.

36. Motamedi H, Asghari B, Tahmasebi H, Arabestani MR. Adhesion Factors and Association with Antibiotic Resistance among Clinical Isolates of Staphylococcus aureus. Iran J Med Microbiol. 2017; 11 (3): 27-36

37. Croes S, Deurenberg RH, Boumans ML, Beisser PS, Neef C, Stobberingh EE. Staphylococcus aureus biofilm formation at the physiologic glucose concentration depends on the S. aureus lineage. BMC Microbiol. 2009; 9: 229. [DOI:10.1186/1471-2180-9-229] [ㅍID] [PMCID]

38. Gad GF, El-Feky MA, El-Rehewy MS, Hassan MA, Abolella H, El-Baky R. M. Detection of icaA, icaD genes and biofilm production by Staphylococcus aureus and Staphylococcus epidermidis isolated from urinary tract catheterized patients. J Infect Dev Ctries. 2009; 3(5): 34251. [DOI:10.3855/jidc.241] [PMID] 